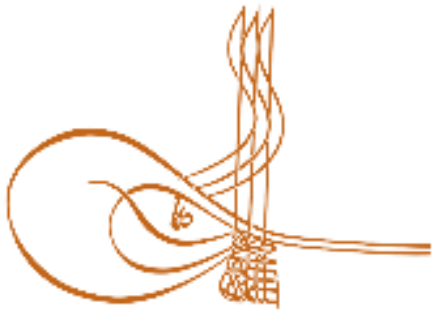

www.turkishstudies.net/social
Turkish Studies - Social Sciences

eISSN: $2667-5617$

Research Article / Araşttrma Makalesi

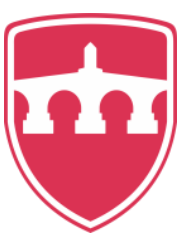

INTERNATIONAL

BALKAN

UNIVERSITY

Sponsored by IBU

\title{
Mısır Lehçesindeki Türkçe Kelimelerin Köken Analizi
}

Etymological Analysis of the Turkısh Words in the Egyptian Dialect

Halil Uysal $^{*}$

\begin{abstract}
Word migration is very common in the relations between languages. There is a certain amount of borrowing and lending in many languages. This applies to Arabic and Turkish as well. The words that are borrowed from Turkish to Arabic exist mostly in local dialects. As far as we can identify, there are 995 Turkish words in the Egyptian dialect. These words are of 36 different origins and types. There are also 38 words whose origin could not be determined. About one-third (305) of the words which we can identify went to the Egyptian dialect through Turkish is Turkish. A significant portion of those words, about two-thirds (189), were observed to have been used since the time of Old Turkish. There are also words from Middle Turkish and Modern Turkish. The words of Turkish origin in the Egyptian dialect are followed by the words that are borrowed from Persian to Turkish and from there to Egyptian Arabic. In addition, Italian, French and Greek words have also been observed to hold a certain amount of space. As far as we can determine, there are 57 Turkish words of Arabic origin in Egyptian Arabic. These are words that are mostly used as names and end with the letter ( $)$ and they are usually written with (ت) in Ottoman Turkish. Behçet, Cevdet, Fikret are some of these types of words. Also, the names ending in ( $\mathbf{-}-\hat{1})$ in Ottoman Turkish have been supplemented with (î) to create proper names in Ottoman Turkish. Such names which don't normally exist in Arabic are now also seen in that language with the effect of Ottoman Turkish. Some of such names are Abdî, Adlî, Avnî, Azmî, Bedrî, Fehmî. It has been observed that some of the words of Arabic origin that passed through Turkish into the Egyptian dialect are words that have gained new meanings in Turkish and then transferred into Egyptian Arabic with these meanings. For example, the word ( أمان Aman), is derived from the Arabic word and expresses meanings such as "being sure, making sure, safety". However, unlike its Arabic meanings, the word is used to strengthen the meaning in sentences expressing various emotions in our language and it has been transferred to Egyptian Arabic in this way.
\end{abstract}

Structured Abstract: Arabic and Turkish languages are regarded among the languages that borrow and lend a lot of words among each other. In this study, the words passing from Turkish to Arabic, especially to Egyptian Arabic were presented.

It is seen that most of the words of Turkic origin in Egyptian Dialect are subculture words that arise from the relations between societies. It is observed that the words we were able to detect have a wide range from trade to military, from architecture to urbanism, from administration to proper names, from food to

\footnotetext{
${ }^{*}$ Dr. Öğr. Üyesi, Sakarya Üniversitesi, İlahiyat Fakültesi, Temel İslam Bilimleri Bölümü Asst. Prof. Dr. Sakarya University, Faculty of Theology, Department of Foundations of Islamic Sciences ORCID 0000-0002-9305-503X

huysal@sakarya.edu.tr
}

Cite as/ Atıf: Uysal, H. (2020). Mısır lehçesindeki Türkçe kelimelerin köken analizi, Turkish Studies - Social, 15(3), 1561-1604. https://dx.doi.org/10.29228/TurkishStudies.40455

Received/Geliş: 07 January/Ocak 2020

Accepted/Kabul: 25 April/Nisan 2020 
clothes, etc. A significant part of these words consists of names. On the other hand, it is in evidence that the adjectives, adverbs, exclamations and formulaic phrases are also in a significant amount. It is understood that the words related to the conceptual field of military are in the first place among the words loaned to the Arabic language from Turkish in terms of frequency of occurrence and prevalence. On the other hand, it seems like Arabs almost have left many areas of social life to Turks and Turkish language along with the streets, markets, trades, social and military institutions. Therefore, it is observed that the occupational suffix $(+\mathrm{cI} /+\mathrm{cU},+c ̧ \mathrm{c} /+c ̧ \mathrm{U})$ of the Turkish language also takes a significant place within the colloquial Arabic besides the conceptual suffix and adjective suffix. Apparently, the language of bureaucracy and craftsman in the Ottoman state reached this far corner of the empire and, in this way, a common terminology was created.

As far as we can identify, the words that passed to Egyptian Arabic through Turkish are of 36 different origins and types. There are also 38 words of which origin cannot be identified.

About one-third (305 of them) of the words, which we can identify the fact that they passed to Egyptian dialect through Turkish, is Turkish. It was observed that a significant part of this kind of words, about two-third (189) of them, has been used since Old Turkish. "Eski (old), oyun (game), parmak (finger), burma (twist), beş (five), bakraç (copper bucket), balta (axe), çavuş (sergeant), çok (very), kargaşa (disorder), dağ (mountain), demir (iron), sancak (flag), süngü (bayonet), çekiç (hammer), çevirme (spin), şiş (skewer), şiş tavuk (chicken skewer), sarma (roll), sol (left), topuk (heel), tuz (salt), aşçı (chef), kazan (cauldron), kazık (stake), kışlak (winter quarter), kol (arm), kürk (fur), yaka (collar), yemiş (berry), yaşmak (veil), yıldız (star), yavaş (slow), yoğurt (yogurt)" are among these words.

In addition to the Old Turkish words, there are also Middle Turkish words such as "pekmez (molasseslike syrup), tatlı (dessert), çörek (round bread), çıkma (balcony), sağ (right), tuğra (tughra), kapı (door), koç (ram), ocak (cooker), bardak (glass)". Turkish.

It was observed that words such as "ökçe (heel), çilek (strawberry), kıç (behind)" passed from Turkey

In addition, it was seen that the words "ikinci kalem (second item), başreis (chief leader), başkatip (chief clerk), başmütercim (chief translator), başmuhdır (chief mukhtar), başmüfettiş (chief inspector), başmüftü (chief mufti), başmühendis (chief engineer), bölük emini (company chief), dörtnal (gallop)" are of Turkish+Arabic origin; words "ayten, baştahta, bilende, bayraktar (flagbearer), dörtçehar, dört cihar" are of Turkish+Persian origin; and the word "başağa (chief agha)" is of Turkish+Mongolian origin.

In addition to these kinds of words, there are Arabic+Turkish words such as "ahlaksiz (immoral), işaretçi (pointer), tahsilci (collector), impertinent (impertinent), haremlik (companionship), haşmetli (majestic), hekimbaşı (chief physician), dükkancı (shopkeeper), silahlık (gun rack), şerbetli (nectaried), fitneci (mischief maker), kumarcı (gambler), mabeyinci (chamberlain), hazırdur / hazrol (be ready)"; Persian+Turkish words such as "astarcı (liner), bostancı (gardener), tüfekçi (gunsmith), hancı (innkeeper), hastalanmak (getting sick), sofracı (table man), sabuncu (soap maker), ateşçi (fireman), kilerci (cellarer), kemençe (kemancha), nazlı (coy), nevin (brand new), yağmacı (looter)"; French+Turkish words such as "avantacı (sponger), valfçı (valve maker), trompetçi (trumpeter), taksici (taxi driver), telgrafçı (telegrapher), televizyoncu (broadcaster), gazeteci (journalist), komisyoncu (broker)"; Italian+Turkish words such as "postac1 (postman), tiyatrocu (theater), dümenci (helmsman), tavlacı (groom), tulumbacı (fireman), kunduracı (shoemaker), lokantacı (restaurateur), makinacı (mechanic)"; Greek+Turkish words such as "temelli (permanent), gümrükçü (customs official), kundakçı (arsonist), lağımcı (sewerman), vernikçi (varnisher)"; Armenian+Turkish words such as "telli (stringed), şenlik (festival)" are also found in Egyptian Arabic.

The word "eczaneci (pharmacist)" stands out as an Arabic+Persian+Turkish word, and the word "Asvanlı" stands out as a word of Ancient Egyptian+Turkish origin.

The words of Turkish origin in the Egyptian dialect are followed by the words that came from Persian to Turkish and from there to Egyptian Arabic. 238 words of this kind were identified among which we can give examples such as "aşikâr (explicit), usta (master), işkembe (tripe), enişte (uncle-in-law), pabuç (shoe), para (money), perde (curtain), puşt (catamite), piyade (infantry), peçe (veil), tava (pan), tımar (grooming), çavdar (rye), çift (couple), zincir (chain), hatun (woman), hastahane (hospital), hoşaf (compote), tane (grain), dilber (beautiful woman), zindan (dungeon), sepet (basket), sert (hard), sincap (squirrel), şadırvan (fountain), çeşni 
(seasoning), çamaşır (clothes), torba (pouch), turşu (pickle), aferin (well done), anbar (storehouse), kahraman (hero), köşk (mansion), kilim (rug), menteşe (hinge), nine (grandma), yahni (stew), yağma (loot)."

As far as we can identify, there are 57 words of Arabic origin in Egyptian Arabic. Regarding some words of this kind, especially the ones used as nouns, there is a situation like this.

In Arabic, words ending with ( $)$ ) turn to names with $ت$ with the impact of Ottoman Turkish. Such names are common in Egyptian Arabic. For example, the Arabic word (نصرة) is written as (نصرت) in Ottoman Turkish. It is seen that it also passed into Egyptian Arabic in this form. It is possible to list some of such names as follows. Behçet, Cevdet, Fikret, Hâlet, Heybet, Hidâyet, Hikmet, Himmet, İffet, İnâyet, İsmet, İzzet, Kudret, Mithat, Necdet, Nimet, Nusret, Nüzhet, Saffet, Servet, Şevket, Talat, Ülfet, Ziynet.

In addition, in Ottoman Turkish, the suffix (î) was added to the names ending with (ي) in order to create proper names in Ottoman Turkish. Such names, which did not exist in Arabic before, are now also seen in Arabic with the effect of Ottoman Turkish. Some of such names are Abdî, Adlî, Avnî, Azmî, Bedrî, Fehmî, Fahrî, Fethî, Fevzî, Feyzî, Fikrî, Şevkî, Şükrî, Hakkî, Hamdî, Hayrî, Hilmî, Kadrî, Lutfî, Mecdî, Nazmî, Nûrî, Remzî, Rüşdî, Rûhî, Sadî, Sabrî, Seyfî, Sırrî, Subhî, Turkî, Ulvî, Vecdî, Vehbî, Vasfî, Zihnî, Zuhdî.

It was observed that some of the words of Arabic origin that passed to the Egyptian dialect through Turkish are words that gained new meanings in Turkish and then passed to Egyptian Arabic with these meanings. For example, the word (أمان / Aman) is derived from the Arabic word أمان and bears meanings such as "being sure, making sure, safety". However, unlike its Arabic meanings, the word is used to corroborate the meaning in sentences expressing various emotions in the Turkish language and it passed to Egyptian Arabic with this meaning.

Some of the words that we were able to identify the fact that they passed to Egyptian dialect through Turkish are of Arabic+Persian origin. There are 26 words of this kind. Words such as "eczane (pharmacy), belki (maybe), cüzdan (wallet), hapishane (prison), hükümdar (ruler), hazinedar (treasurer), rasathane (observatory), silahtar (armourer), şifahane (hospital), kütüphane (library), misafirhane (guesthouse), makasdar (fitter), mühendishane (engineer school), nizamname (regulations)" are examples of this type.

It was observed that words of Turkish and Persian origin in Egyptian Arabic are followed by Italian, French and Greek words respectively.

Keywords: Turkish, Arabic, Languages, Egyptian Dialect, Analysis, Origin.

Öz: Diller arası ilişkilerde kelime göçleri sıkça rastlanılan durumlardan birisidir. Birçok dil için alıntı ve verinti belirli oranlarda söz konusudur. Benzer bir durum Arapça ve Türkçe için de geçerlidir. Türkçe'den Arapça'ya geçen kelimeler daha çok yerel lehçelerde varlıklarını sürdürmektedirler. Tespit edebildiğimiz kadarıyla Mısır lehçesinde 995 Türkçe sözcük bulunmaktadır. Bu sözcükler 36 farklı kökende ve türdedir. Ayrıca 38 adet kökeni belirlenemeyen sözcük vardır. Misır lehçesine Türkçe aracılığıyla geçtiğini belirleyebildiğimiz sözcüklerin yaklaşık üçte biri (305 tanesi) Türkçe'dir. Bu türden kelimelerin önemli bir bölümünün, yaklaşık üçte ikisinin (189) Eski Türkçe'den beri kullanılan kelimeler olduğu gözlemlenmiştir. Ayrıca Orta Türkçe ve Türkiye Türkçesi’nden kelimeler de bulunmaktadır. Mısır lehçesindeki Türkçe kökenli sözcükleri, Farsça'dan Türkçe'ye, oradan da Mısır Arapçasına geçen sözcükler takip etmektedir. Ayrıca İtalyanca, Fransızca ve Yunanca sözcüklerin de belirli bir yekûn tuttukları gözlemlenmiştir. Mısır Arapçasında tespit edebildiğimiz kadarıyla 57 Arapça kökenli Türkçe sözcük de bulunmaktadır. Bu kelimeler daha çok isim olarak kullanılan ve (ڤ) harfiyle biten kelimelerdir ve Osmanlı Türkçesi'nde, genellikle (ت) harfiyle yazılmaktadır. Behçet, Cevdet, Fikret gibi kelimeler bu türden kelimelerden bazılarıdır. Ayrıca Osmanlı Türkçesinde (ي) î) ile biten adlara (î) eki getirilerek Osmanlı Türkçesinde özel adlar oluşturulmuştur. Arapçada olmayan bu türden adlar Osmanlı Türkçenin etkisiyle Arapçada da görülmektedir. Bu türden adlardan bazıları şunlardır: Abdî, Adlî, Avnî, Azmî, Bedrî, Fehmî. Mısır lehçesine Türkçe'den geçen Arapça kökenli sözcüklerin bazılarının ise, Türkçe'de yeni anlam kazanan ve bu anlamlarıyla Mısır Arapçasına geçen sözcükler oldukları müşahede edilmiştir. Örneğin (أَّان / Aman) kelimesi, Araça أمان kelimesinden gelmekte ve "emin olma, emin k1lma, emniyet" gibi anlamları dile getirmektedir. Ancak kelime Arapçadaki anlamlarından farklı olarak, dilimizde çeşitli duyguları ifâde eden cümlelerde anlamı güçlendirmek için kullanılmaktadır ve Mısır Arapçasına da bu şekliyle geçmiştir.

www.turkishstudies.net/social 
Anahtar Kelimeler: Türkçe, Arapça, Dil, Mısır Lehçesi, Analiz, Köken.

\section{Giriş}

Türkçe, Farsça ve Arapça'dan pek çok kelime aldığı gibi aynı zamanda bu dillere de birçok kelime vermiştir. Aynı coğrafyayı paylaşan ulusların pekçok alanda birbirlerinden etkilendikleri gibi dil alanında da etkileşimin olması ve sözcük alıp vermeleri son derece olağandır.

Dilbilimciler dillerarası etkileşimi, alıntı ve verintileri inceleyen pek çok araştırmalar yapmışlardır ve yapmaya devam etmektedirler. Bu bağlamda Arapça ve Türkçe arasındaki ilişkilere yönelik olarak da pek çok çalışma yapılmıştır. Biz de spesifik olarak Mısır Lehçesindeki Türkçe Kelimelere yönelik, "Mısır Lehçesindeki Türkçe Kelimeler" başlıklı bir çalışma yapmıştık ve bu çalışmamızda yer alan sözcüklerin kökenlerine yönelik müstakil bir çalışmanın gerekliliğine işaret etmiştik. Bu çerçevede elinizde bulunan çalışmada, Mısır Lehçesindeki Türkçe kelimelerin köken analizini yapmaya çalışacağız. Anılan kelimelerin anlamlarına ve kaynaklarına önceki çalışmamızda değinildiği için bu çalışmamızda tekrar yer vermeyeceğiz.

Çalışmamızda önceki çalışmalarımızdaki kaynaklara ek olarak, özellikle köken bilgisi konusunda başta Kubbealtı Sözlüğ̈̈ olmak üzere, TDK Türkçe Sözlük ve Türkiye Türkçesindeki Türkçe Sözcüklerin Köken Bilgisi Sözlüğü isimli eserden ve isimleri kaynakçada yazılı diğer kaynaklardan azami derecede yararlandık.

\section{Mısır Arapçasına Türkçe Kanalıyla Giren Sözcükerin Kökenlerine Göre Dağılımı}

\section{Almanca Kökenli Sözcükler}

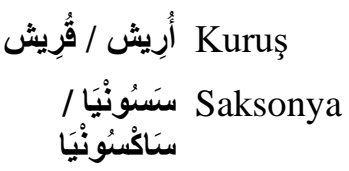

\section{Arapça Kökenli Sözcükler}

1

2

3

4

5

6

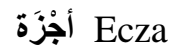

Ülfet

ألْمَظ Elmas

Aman

Budala

Baharat

Tuhaf

Tiryak
Alm. Groschen < Lat. denarius grossus "büyük sikke".

Alm. Saksonya yer adından.

Ar. $c u z$ 'un çoğul şekli $e c z \bar{a}^{\prime}$. [Tekil gibi de kullanılır] Yazım ve söyleniş şekli Türkçe'dir.

Ar. ulfet.

Ar. el-mās < Yun. adamas "yenilmez, mağlûp olmaz". Form Türkçe'dir.

Ar. emān "emin olma, emin k1lma, emniyet". [Kelime, Arapçadaki anlamlarından farklı olarak, bugün dilimizde çeşitli duyguları ifâde eden cümlelerde anlamı güçlendirmek için kullanılır]

Ar. bedil "değişmiş olan, karş1l1k"1n çoğul şekli budelä' dan. [Türkçe'de tekil anlamında kullanılır].

Ar. behār > bahār ve çoğul eki -āt ile baharat.

Ar. tuhfe "hediye, yeni şey"in çoğulu tuhaf.

Ar. tiry $\bar{a} k<$ Fars. tiry $\bar{a} k<$ Yun. 


\begin{tabular}{|c|c|c|}
\hline 9 & تَفِيَة Tevhide & Ar. vahdet "bir olmak"tan tevhid' in dişil formu. \\
\hline 10 & تَكَيَّة & Ar. tekye'den. \\
\hline 11 & تَتُور Tandır / Tennur & Ar. tennū $r$ 'dan ayrışma ile tendür $>$ tandır. \\
\hline 12 & تَنُُورَة & Ar. tennure. \\
\hline 13 & Servet & Ar. servet. \\
\hline 14 & جَامُوس Camı / Câmus & Ar. $c \bar{a} m \bar{u} s<$ Fars. gāmmīş $<$ gā vmiş. \\
\hline 15 & حِثْمَتَ Haşmet & Ar. haşsem > haş̧met. [Türkçe'de türetilmiştir]. \\
\hline 16 & حِكْمَت Hikmet & Ar. hikmet. \\
\hline 17 & حَيَات Hayat & Ar. hayāt. \\
\hline 18 & خَزْنَة & Ar. hazine. \\
\hline 19 & دَفَتُّر Defter & Ar. - Fars. defter < Yun. diphtheri "deri; parşömen". \\
\hline 20 & دَدْلْيز Dehliz & Ar. dehliz < Fars. dihliz. \\
\hline 21 & Devlet & Ar. devlet. \\
\hline 22 & Rafet & Ar. Form Türkçe'dir. \\
\hline 23 & رَشَتْنَة Reşme & Ar. reşme. \\
\hline 24 & شَافَفِى Şefika & Ar. şevkī’ den. \\
\hline 25 & شَرَبَات S Şerbet & Ar. şurb “içmek”'ten şer-bet. Form ve kullanım Türkçe'dir. \\
\hline 26 & شَفَعَات Şefaat & Ar. şefā 'at. Form Türkçe’dir. \\
\hline 27 & Çul & Ar. cull'den. < Fars. cull. Form Türkçe'dir. \\
\hline 28 & ش شَوْكَت Şevket & Ar. şevket. Form Türkçe'dir. \\
\hline 29 & صَفْوَت Saffet / Safvet & Ar. șafvet. Form Türkçe'dir. \\
\hline 30 & طَابَيَة & Ar. ta 'biye "askeri hazırlamak"tan. \\
\hline 31 & طَاسنَة Tas & Ar. $t \bar{a} s<$ Fars. $t \bar{a} s$. Form Türkçe'dir. \\
\hline 32 & 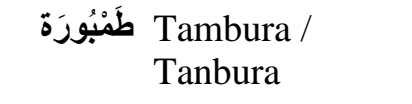 & Ar. tanbür < Fars. tenbū r'dan. \\
\hline 33 & ظَابط Zabit & Ar. $\dot{z} a b t$ "korumak; yakalamak, tutmak"tan $\dot{z} \bar{a} b i t$. \\
\hline 34 & عَدَلَت Adalet & Ar. 'adālet. Form Türkçe'dir. \\
\hline 35 & Arzuhal & $\begin{array}{l}\text { Ar. 'arż "sunma, bildirme" ve } h \bar{a} l \text { "durum” ile 'arż-ı } h \bar{a} l \text {. } \\
\text { Türkçe'de yeni anlam kazanmiştır. }\end{array}$ \\
\hline 36 & İzzet & Ar. 'izzet. Form Türkçe'dir. \\
\hline 37 & عِصنمَت İsmet & Ar. 'ismet. Form Türkçe'dir. \\
\hline 38 & عِفَّت İffet & Ar. 'iffet Form Türkçe'dir. \\
\hline 39 & عَنَايَات İnayât & Ar. 'ināyet'den. Form Türkçe'dir. \\
\hline 40 & عِنَايَت İnayet & Ar. 'ināyet. Form Türkçe’dir. \\
\hline 41 & فَاِظ Faiz & Ar. $f e y \dot{z}$ “çoğalmak”tan $f a \bar{\prime} ' i z$. Form Türkçe'dir. \\
\hline
\end{tabular}


Ferhat قََائمْنَقَام Kaymakam Kaَالْفَة

Gismet

مَاوي Mavi

Mithat

مرِفَتَت Mürüvvet

مِشْوَار Mişvar

نَجْدَت Necdet

نَنَنَأَت Neşet

Nusret

Navlun

هَلَبَتَ تونَ Elbet / Helbet

هِمّت Himmet

Yَيَتِّم Yeşim

يَلَْلَ Yallah
Ar. ferhat. Form Türkçe'dir.

Ar. $k \bar{a}{ }^{\prime} i m$ ve makām ile $k \bar{a}$ 'im-i makām > kā'im-makām'dan.

Ar. halife "birinden sonra gelen"den.

Ar. kismet. Form Türkçe'dir.

Ar. $m \bar{a}$ ' "su" ve nispet eki $-i$ ile $m \bar{a} ' i$ "su renginde olan".

Ar. medḥ “övmek”ten midhat. Form Türkçe'dir.

Ar. mer' "erkek, adam"dan murū'et > muruvvet. Form Türkçe'dir.

Ar. şevr "görünüşte güzel olmak; petekten bal çıkarmak; hayvanı müşteriye göstermek için yürütmek"ten mişvār)

Ar. Necdet. Form Türkçe'dir.

Ar. neş'et.

Ar. nușret. Form Türkçe'dir.

Ar. nāvlūn < Yun. naulon < naus "gemi".

Ar. harf-i târif el- ve betteten "kesin olarak"tan $e l$ bettete $>$ el-bette $>$ elbet.

Ar. himmet. Form Türkçe'dir.

Ar. yeşm.

Ar. $y \bar{a}$ Allāh'dan. Form ve anlam Türkçe'dir.

\section{Arapça + Farsça Kökenli Sözcükler}

1e / Eczâhâne
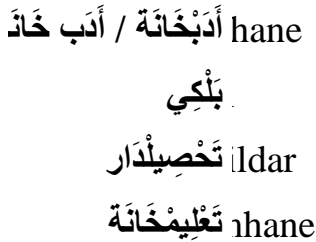

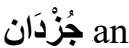

Shane

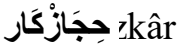

üşah حُنْن شَنَاه

Imdar

1edar / Haznedar dar / Devatdar

hane $c z \bar{a}$ ' ve Fars. hāne "ev, yer" ile eczā-hāne.

deb ve Fars. hāne "ev, yer" ile edeb-hāne.

$e l$ "ancak, fakat"tan Fars. $k i$ ile bel+ki.

ıhșil ve Fars. dār "sâhip ve mâlik olan" ile tahṣil-dār.

I 'lim ve Fars. hāne "ev, yer" ile ta lim-hāane.

uz' "parça" ve Fars. -dān ekiyle cuz'-dān.

$a b s$ ve Fars. hāne "ev, yer" ile habs-ḩāne.

$i c \bar{a} z$ ve Fars. $-k \bar{a} r$ ekiyle hicāa-kār

usn "güzellik" ve Fars. şāh ile husn-i şāh.

$u k m$ ve Fars. dār "sâhip olan" ile hukum-dār.

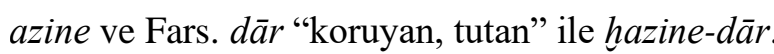

evāt $>$ divit ve Fars. dār "sâhip olan" ile devāt-dār > divit$d \bar{a} r$.

xṣad "gözetleme" ve Fars. hāne "ev, yer" ile raṣad-hāne. 


\begin{tabular}{|c|c|c|}
\hline 14 & tar سِلِدَدَر & ilāh ve Fars. $d \bar{a} r$ "sâhip ve mâlik olan" ile silāh-dār. \\
\hline 15 & 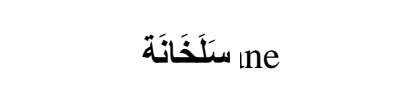 & $\begin{array}{l}\text { elh “yüzmek, derisini çıkarmak"tan Fars. h̆āne "ev, yer" } \\
\text { ile selh-hāane > salhāne. }\end{array}$ \\
\hline 16 & ane & $\begin{array}{l}\text { if } \bar{a} \text { ' "hastalıktan kurtulma" ve Fars. ḩāne "ev, yer" ile şifā- } \\
\text { hâne. }\end{array}$ \\
\hline 17 & 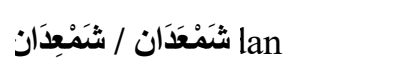 & em ‘"mum” ve Fars. dān ekiyle şem 'dān'dan. \\
\hline 18 & قَِانُونْنَامَة nâme & $\bar{a} n \bar{u} n$ ve Fars. nāme "yazıll şey" ile kānūn-nāme. \\
\hline 19 & 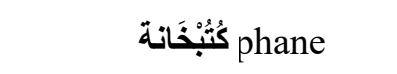 & utub "kitaplar" ve Fars. hāane "ev, yer" ile kütüb-hāne \\
\hline 20 & 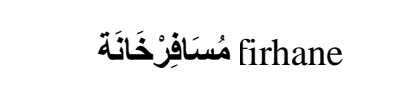 & $\begin{array}{l}\text { iisāfir < musāfir ve Fars. hāane "ev, yer" ile misäfir-hāne- } \\
\text { musāfir-hāne. }\end{array}$ \\
\hline 21 & Isdar & $\begin{array}{l}\text { ass "kesmek"ten mikasṣ > makas ve Fars. dār "sâhip olan, } \\
\text { tutan" ile makaṣ-dār. }\end{array}$ \\
\hline 22 & 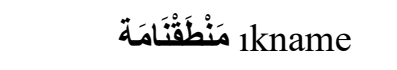 & uṭ "konuşmak, söz söylemek"ten manțik + Fars. nāme. \\
\hline 23 & nndishane & unhendis ve Fars. hāne “ev, yer” ile muhendis-ḩāne. \\
\hline 24 & nname & izām "usûl, kural"dan Fars. nāme "yazılı şey" ile nizām-nāme \\
\hline 25 & 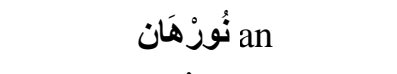 & $\bar{u} r+$ Fars. $\underline{h} \bar{a} n$ \\
\hline 26 & Shane & arak + Fars. hāne "ev, yer". \\
\hline
\end{tabular}

\section{Arapça + Farsça + Türkçe Kökenli Sözcükler}

Ar. eczāa' + Fars. hāne "ev, yer" ile eczāa-hāne ve Türk. -ci.

\section{Arapça + Türkçe Kökenli Sözcükler}

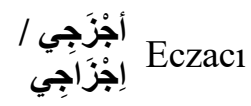

3

4

5

6

7

8

9

10

11
Ahlaksız

İhvanc1

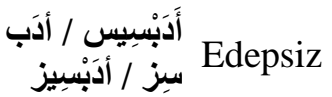

İşaretçi

Baramilci

Bereket versin

Tahrirci

Tahsilci

Tühfçü
Ar. $c u z^{\prime}$ un çoğul şekli $e c z \bar{a}^{\prime}+$ Türk. -ci.

Ar. hulk "yaratılış, tabiat, huy”un çoğul şekli ahlāk + Türk. siz.

Ar. ah "kardeş, arkadaş"1n çoğul şekli iḩvān + Türk. -c1.

Ar. $e d e b+$ Türk. $-s l z$

Arap. işâret + Türk. -ci.

Ar. bermīl "fiçı" nın çoğulu barâmīl + Türk. -ci.

Ar. bereket $+<$ vir-mek $<$ Eski Türk. bir-mek.

Ar. harr "düzeltmek, süslemek"ten tahrir + Türk. -ci.

Ar. hușūl "toplamak, elde etmek, meydana gelmek"ten tahṣil + Türk. -ci.

Ar. tuhf + Türk. -ci. 


\section{2}

13

14

15

16

17

18

19
Tahlisci

Tezkereci

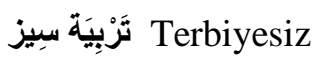

Teşrifatç1

Talimci

Savrac1

جلاَجِي

Çorapçı, Çorap

جَوْرَبْجِي Yapicis1/ Üreticisi

حَرَمْلِك Haremlik

حِنْمَتُلُو

حَضْرَتْلَرِي

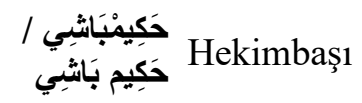

مَلْوَاجِى

Hamamc1

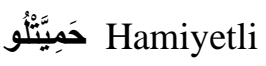

خَاطْرِتْثِنِ Hatır için

خَمَوْزجِي Hamurcu

Decayici

دُكَانْجِى Dükkanc1

دَوَّكَتُْو

رِفْفَتُؤُ مِ

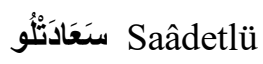

سنَلَكْبِك Selamlik

Silahlık

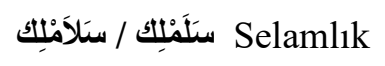

سَنَاحَتُُْو Semâhatli

شَرَبَتُبْي

Sedefçi

Sohbetçi
Ar. halāṣ "kurtulmak”tan tahliṣ + Türk. -ci.

Ar. tezkire + Türk. -ci.

Ar. rebv “yetişmek, büyümek”ten terbiye + Türk. -siz.

Ar. teşrif ve çoğul eki -āt ile teşrifāt + Türk. -ci.

Ar. ta'lìm + Türk. -ci.

Ar. savra "ihtilal, devrim" + Türk. -ci.

Ar. cilā' + Türk. -ci.

Ar. curāb $<$ Fars. gurā $b+$ Türk. -ci.

Ar. hirmān "yasaklamak”tan harem + Türk. -lik.

Ar. haşem > haşmet + Türk. -li.

Ar. hużūr "hazır bulunmak, yakın olmak"tan hażret + Türk. ler $+\mathrm{i}$.

Ar. hakim'den hekim + Eski Türk. $b \bar{a} s ̧+1$.

Ar. halvā + Türk. -ci.

Ar. hammām + Türk. -ci.

Ar. hamiyyet + Türk. -li.

Ar. huțūr "akla gelmek" ve hățir "kalp"ten hățir + Eski

Türk. üçün [> içün > için] < uçun < uç "son, hedef; sebep" ve araç hâli eki $+n$.

Ar. hamir + Türk. -ci.

Ar. decâyic "kümes hayvanlarl" + Türk. -ci.

Ar. dukkān < Fars. + Türk. -ci.

Ar. devlet + Türk. -li.

Ar. rif'at + Türk. -lü.

Ar. sa'ādet + Türk. -lü.

Ar. selâm + Türk. -lık.

Ar. silāh + Türk. -lık.

Ar. selâm + Türk. -lık.

Ar. semāḥt + Türk. -li.

Ar. şurb “içmek”ten şer-bet + Türk. -li.

Ar. șadef + Türk. -çi.

Ar. șuhbet + Türk. -çi. 


\begin{tabular}{|c|c|c|}
\hline 41 & Arzuhalci & 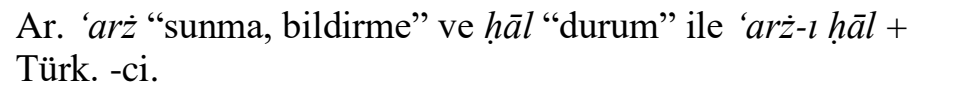 \\
\hline 42 & İzzetlü & Ar. 'izzet + Türk. -lü. \\
\hline 43 & Aُطُوفَتَُّو & $\begin{array}{l}\text { Ar. 'atf > 'ațūf “çok merhametli"den 'ațūfet) [Osmanlı } \\
\text { Türkçesi' nde türetilmiştir] + Türk. -lü. }\end{array}$ \\
\hline 44 & فَاِِظْجِي Faizci & Ar. $f e y \dot{z}$ “çoğalmak”tan $f \bar{a} ’ \dot{i z}+$ Türk. -ci. \\
\hline 45 & Fitneci & Ar. fitne "deneme, imtihan" + Türk. -ci. \\
\hline 46 & 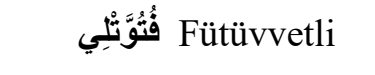 & Ar. fütüvvet + Türk. -li. \\
\hline 47 & 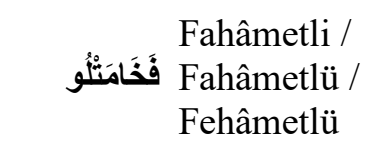 & Ar. fehāmet + Türk. -li. \\
\hline 48 & $\begin{array}{c}\text { Faziletli / } \\
\text { فَضِيَتَُْو } \text { Fazîletlü }\end{array}$ & Ar. fażilet + Türk. -li. \\
\hline 49 & Favdac1 & Ar. favda + Türk. -c1. \\
\hline 50 & مََانُونْجِي Kanuncu & Ar. kāāīn < Yun. kanon "kural" + Türk. -cu. \\
\hline 51 & Katarc1 & Ar. kațar + Türk. -c1. \\
\hline 52 & Kumarc1 & Ar. kimāar + Türk. -c1. \\
\hline 53 & Kumaşç1 & Ar. kumāşs + Türk. -çı. \\
\hline 54 & Kumsanc1 & Ar. kumsân + Türk. -c1. \\
\hline 55 & Kandilci & Ar. kindil < Lat. candela "mum" + Türk. -ci. \\
\hline 56 & Sebapç1 & Ar. kebāb + Türk. ç1. \\
\hline 57 & كُتَبْجِي Kütüpçü & Ar. Kitâb'dan kütüp “kitaplar” + Türk. -çü. \\
\hline 58 & مَابَيْنِجي Mabeyinci & $\begin{array}{l}\text { Ar. } m \bar{a} \text { "şey" ve beyne > beyn "ara"dan } m \bar{a} \text {-beyn) [Kelime } \\
\text { Türkçe'de yeni anlamlar kazanmıştır] + Türk. -ci. }\end{array}$ \\
\hline 59 & مavnac1 & $\begin{array}{l}\text { Ar. ma 'ūne > mavuna > mavna "erzak nakline mahsus } \\
\text { gemi" + Türk. -c1. }\end{array}$ \\
\hline 60 & Muhasebeci & Ar. hisāa "saymak, hesap etmek"ten muḥāsebe + Türk. -ci. \\
\hline 61 & محِوَالْجِي Mihvalc1 & Ar. mihvâl + Türk. -c1. \\
\hline 62 & Mahzenci & $\begin{array}{l}\text { Ar. hazn "malı kasa, dolap vb. yerde saklamak"tan mahzen + } \\
\text { Türk. -ci. }\end{array}$ \\
\hline 63 & مِدْفَجْجي Midfac1 & $\begin{array}{l}\text { Ar. def' "itmek, uzaklaştırmak"tan midfa ) [“Top" anlam } \\
\text { Türkçe'de türetilmiştir] +Türk. -cı. }\end{array}$ \\
\hline 64 & Mizrakç1 & Ar. zerk “mızrak atmak”tan mizrāk + Türk. -çı. \\
\hline 65 & مَطُبْعِجِ Matbaac1 & Ar. țab' "kitap basmak"tan mațba'a + Türk. -c1. \\
\hline 66 & Macuncu & $\begin{array}{l}\text { Ar. 'acn "hamur kıvâmına getirmek, yoğurmak"tan } m a \text { 'cūn } \\
+ \text { Türk. -cu. }\end{array}$ \\
\hline 67 & Miftahc1 & Ar. fetḥ “açmak"tan miftāḥ + Türk. -c1. \\
\hline
\end{tabular}


68

مَكْتَبْجِي Mektepci

69

70

مَكْوَجِي Mekveci

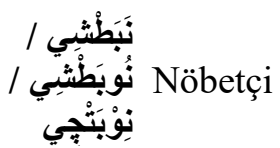

71
Ar. ketb "yazmak"tan mekteb "yazacak yer, yazıhâne, büro" [Anlam Türkçe'de ortaya çıkmıştır] + Türk. -ci.

Ar. $m e k v \hat{a}+$ Türk. -ci.

Ar. - Fars. nevbet + Türk. -çi.

Ar. huż̄ur "hazır olmak, bir yerde bulunmak"tan hāżir + Eski Türk. ol.

\section{Bulgarca Kökenli Sözcükler}

$\begin{array}{ll}\text { كُبْثَة Kopça } & \text { Bulg. kopçe - kopça < Mac. kapocs. } \\ \text { وِشْنَة Vişne } & \text { Bulg. vişna. }\end{array}$

\section{7. Çince Kökenli Sözcükler}

شَاى Çay

Çin. ça-ye; Türkçe'ye muhtemelen Farsça'dan geçmiştir.

\section{Ermenice Kökenli Sözcükler}

$$
\begin{aligned}
& \text { بَزَوَنْج / بَزَوَنْكُ Pezevenk } \quad \text { Erm. pozavak. } \\
& \text { بَتْجَر Pancar Pancar. }
\end{aligned}
$$

\section{Ermenice + Türkçe Kökenli Sözcükler}

$$
\text { Telli }
$$

Erm. tel + Türk. -li.

Erm. şen + Türk. -lik.

10. Eski Mısır + Türkçe Kökenli Sözcükler

\section{Farsça Kökenli Sözcükler}

Fars. ustād'dan.

Fars. ustād.

Fars. şikem "karın" ve $\bar{a} b \bar{a}$ "yemek"ten şikem$\bar{a} b \bar{a}>$ şikembe $>$ işkembe.

Fars. efyūn < Yun. opion.

Fars. enkişte' den.

Fars. $p \bar{a}$ "ayak" ve $p \bar{u} s ̧$ "örten" ile $p \bar{a}-p \bar{u} s ̧$ 'tan.

Fars. pāre "parça, gümüş parçası"ndan. 


\begin{tabular}{|c|c|c|}
\hline 10 & Pazar & Fars. $b \bar{a} z \bar{a} r^{\prime}$ dan. \\
\hline 11 & بَالكوظة Paluze & Fars. pālūde "süzülmüşsten. \\
\hline 12 & Patlican بتجنان & Fars. bādingān. \\
\hline 13 & بaht & Fars. baht. \\
\hline 14 & بَخْشَوَان Bahçıvan & $\begin{array}{l}\text { Fars. } b \bar{a} \dot{g} c ̧ e \text { ve -bān ekiyle } b \bar{a} \dot{g} c ̧ e-b \bar{a} n \text { 'dan } b \bar{a} \dot{g} c ̧ e- \\
\text { vān > bahçevan > bahçıvan. }\end{array}$ \\
\hline 15 & Firdevs & Fars. Firdevs. \\
\hline 16 & Pergel بَرْجِلْ Perel & Fars. pergāl. \\
\hline 17 & بَرْدَايَة & Fars. perde. \\
\hline 18 & $\begin{array}{l}\text { Merzengûş / } \\
\text { بَرْدَقُقُش merzencuş }\end{array}$ & Fars. merzengûş. \\
\hline 19 & بirşam / Perçin & Fars. perçin. \\
\hline 20 & Perçinci & Fars. perçin + Türk. -ci. \\
\hline 21 & 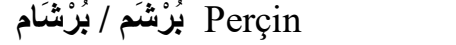 & Fars. perçin. \\
\hline 22 & Pervaz & Fars. pervez'den. \\
\hline 23 & بَسنْ Bes / Pes & Fars. bes. \\
\hline 24 & Bostan & $\begin{array}{l}\text { Fars. būstān, bū "koku" ve yer bildiren -istān > - } \\
\text { sitān ekiyle bū -sitān > būstān "koku yeri". }\end{array}$ \\
\hline 25 & Pُشُثْت Puşt & Fars. puşt "arka"dan. \\
\hline 26 & Peşrev & Fars. piş “ön” ve rev "giden" ile piş-rev. \\
\hline 27 & Peşkir & Fars. piş "ön” ve gir ile piş-gir "öne tutulan şey"den. \\
\hline 28 & Pişman & Fars. peşimān'dan. \\
\hline 29 & / بَخْشَيَِيش & Fars. bahşiden "bağışlamak"tan bahşiş. \\
\hline 30 & 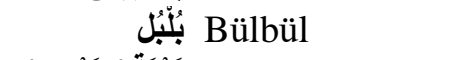 & Fars. bulbul. \\
\hline 31 & 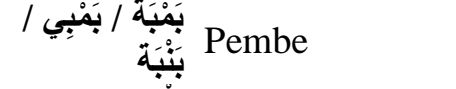 & Fars. penbe "pamuk"tan (?) \\
\hline 32 & Pَنْجَرَة Pencere & Fars. pencer $>$ pencere. \\
\hline 33 & بَتبن Bent & Fars. bend. \\
\hline 34 & بَتْزَهِير Panzehir & Fars. $p \bar{a} d$ "koruyucu" ve zehr "zehir" ile $p \bar{a} d-z e h r$ ' den. \\
\hline 35 & $\begin{array}{l}\text { Benefşe / } \\
\text { بَفَفْسَج } \\
\text { Menekşe }\end{array}$ & Benefşe: Fars. benefşe. Menekşe: Fars. benefşse'den. \\
\hline 36 & Bahadır & Fars. bahādur $<$ Moğ. baġatur. \\
\hline 37 & بَهْرِيز Perhiz & Fars. perhiz. \\
\hline 38 & بَهْلَوَان Pehlivan & $\begin{array}{l}\text { Fars. pehlevān "yiğit, kahraman") [Kelimenin 'güreşçi' } \\
\text { anlamı Türkçe'de ortaya çıkmıştır]. }\end{array}$ \\
\hline 39 & Borânî & Fars. bürāni. \\
\hline 40 & بوز Büz & Fars. \\
\hline 41 & Buse بُوسَة & $\begin{array}{l}\text { Fars. būs > bûse. } \\
\text { Fars. büze; bâz1 dilcilere göre ise Türkçe olan kelimenin }\end{array}$ \\
\hline 42 & بُوظَة Boza & $\begin{array}{l}\text { nihâî kökü kesin biçimde belli değildir) [Kelime Türkçe'den } \\
\text { Arapça ve Farsça'ya, Balkan dillerine, Macarca ve Rusça'ya } \\
\text { da geçmiştir]. }\end{array}$ \\
\hline 43 & Polat & Fars. pūlād. \\
\hline 44 & بِيَادة & Fars. piyade. \\
\hline 45 & Peçe & Fars. beçe-beççe-peççe-peçe. \\
\hline 46 & Tava & Fars. $t \bar{a} b \bar{a}-t \bar{a} b e-t \bar{a} v e$ \\
\hline 47 & Taht & Fars. taht. \\
\hline 48 & Tahtaboş تَنتَبُوش Ta & Fars. tahte "tahta" ve pūş "örten" > tahte-pūş’tan. \\
\hline
\end{tabular}




\begin{tabular}{|c|c|c|}
\hline 49 & Tahta & Fars. tahte "biçilmiş ağaç". \\
\hline 50 & Tahtırevan & Fars. taht "koltuk" ve revān "giden" ile taht-ı revan. \\
\hline 51 & تَزَزْي Terzi & Fars. derzi'den. \\
\hline 52 & تَزْجَه Tezgâh & Fars. destgāh'tan. \\
\hline 53 & تَطْمِير Timar & Fars. timārr. \\
\hline 54 & $\begin{array}{l}\text { Tembel / } \\
\text { تَمْبَل /تَنْبَل }\end{array}$ & Fars. tenbel. \\
\hline 55 & Tembelhane & Fars. tenbel ve hăne "ev, yer" ile tenbel-hăne. \\
\hline 56 & تُوتِ Dut & Fars. $t \bar{u} t-t \bar{u} d$ \\
\hline 57 & Tüfekhane & Fars. tufeng ve ḩāne "ev, yer” ile tenbel-hāne. \\
\hline 58 & جَاشْنْكير Çeşnici / & $\begin{array}{l}\text { Fars. çăşsni "tat, lezzet" ve gir "tutan, alan" ile çāşsni-gir. } \\
\text { Fars. çășni "tat, lezzet" + Türk. -ci. }\end{array}$ \\
\hline 59 & جَالَة Jale & Fars. jāle. \\
\hline 60 & جَاوَادَار Çavdar & Fars. çūdār'dan. \\
\hline 61 & 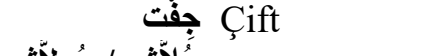 & Fars. cuft “zevç, eş; tek olmayan"dan. \\
\hline 62 & 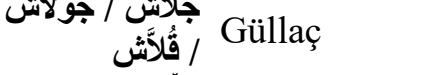 & Fars. gulāc'dan. \\
\hline 63 & Gülbahar & Fars. gul ve behār'dan gul-i behār > gul-behar. \\
\hline 64 & Gülsüm & Fars. gülsün. \\
\hline 65 & جُلْنَار Gülnar & Fars. gul ve $n \bar{a} r$ ' dan $n \bar{a} r-l$ gul > gul-nār. \\
\hline 66 & 罗 Cambaz / & Fars. $c \bar{a} n$ "ruh" ve -bāz "oynayan" ile $c \bar{a} n-b \bar{a} z$. \\
\hline $\begin{array}{l}67 \\
68\end{array}$ & 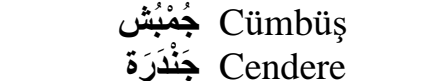 & $\begin{array}{l}\text { Fars. cunbiden "kımıldamak"tan cunbiş > cünbüss. } \\
\text { Fars. cendere. }\end{array}$ \\
\hline 69 & Z Z جَنْزِير / مجنزر & As \\
\hline 70 & جِهَارْكَاه & Fars. çārgā. \\
\hline 71 & Çuha & $\begin{array}{l}\text { Fars. çūh } h \bar{a}-c ̧ \bar{u} h a) \text { [Eski metinlerde çuka şeklinde } \\
\text { geçmektedir]. }\end{array}$ \\
\hline 72 & Cihan & Fars. cihan. \\
\hline 73 & شَانَة / خَانَة Hane & Fars. hāne. \\
\hline 74 & خَاتُون Hatun & Fars. hāàūn < Soğd. hvvaten. \\
\hline 75 & خَام Ham & Fars. hām. \\
\hline 76 & خَان Han & Fars. hān. \\
\hline 77 & Hidiv & Fars. hidiv. \\
\hline 78 & خُرْدَة & Fars. hurde “yenilmiş şey, kırıntı”. \\
\hline 79 & خَسْنَة Hasta & Fars. hasten "yaralanmak, incinmek"ten haste "yaralı". \\
\hline 80 & خَسْتَخَانَة Hastahane & Fars. hasta ve hāne "ev, yer" ile hasta-hāne. \\
\hline 81 & خُشَتَف Hoşaf & Fars. hōoss ve $\bar{a} b$ “su” ile $h \bar{o} \bar{s}-\bar{a} b$ 'dan. \\
\hline 82 & خَوَاجَة & Fars. $\underline{h} \bar{a} c e$ "efendi"den. \\
\hline 83 & خُوجَة & Fars. $\underline{h} \bar{a} c e$ "efendi"den h̆ōca. \\
\hline 84 & خُورْشِيد Hurşit & Fars. \\
\hline 85 & دَادَة Dad1 & Fars. $d \bar{a} d \bar{u}$ 'dan. \\
\hline 86 & دانَة Tane & Fars. dāne'den. \\
\hline 87 & دُرْدِى Tortu & Fars. durd $>$ durdi' den. \\
\hline 88 & Derviş دَرْوِش D D & Fars. derviş. \\
\hline 89 & دَسنَتَة Deste & Fars. dest "el"den deste. \\
\hline 90 & Destur & Fars. destur. \\
\hline 91 & Defterhane & Fars. defter ve hāne “ev, yer" ile defter-ḩāne. \\
\hline 92 & Defterdar & Fars. defter ve dāa "tutan" ile defter-dār. \\
\hline
\end{tabular}

Turkish Studies - Social, 15(3) 


\begin{tabular}{|c|c|c|}
\hline 93 & Dilaver & Fars. dil "gönül" ve āver "getiren, taşıyan" ile dil-āver. \\
\hline 94 & Dilber & Fars. dil "gönül” ve ber "alan, götüren" ile dil-ber. \\
\hline 95 & Dubara & Fars. $d \bar{u}$ "iki" ve $b \bar{a} r e$ "kere"den $d \bar{u}$-bāre. \\
\hline 96 & دُودُو Dudu & Fars. țūti den. \\
\hline 97 & دُوسنة Dü-se & Fars. $d \bar{u}$ "iki" ve se "üç" ile dü-se. \\
\hline 98 & دُوشَش Dü-şeş & Fars. $d \bar{u}$ "iki" ve şeş "altı" ile $d \bar{u}$-şeş. \\
\hline 99 & دُوكَاه Dügâh & \\
\hline 100 & Dolap دُولاَب & $\begin{array}{l}\text { Fars. dōlāb'dan; eski metinlerde asıl şekliyle dōlāb- } \\
\text { dūlāb olarak da kullanılmıştır. }\end{array}$ \\
\hline 101 & Diba, Dibac & Fars. dibā. \\
\hline 102 & Dِديَّاجَة Dibace & $\begin{array}{l}\text { Fars. dibā-ce "bir tür has ipek parçası". [Kelime önceleri } \\
\text { yazma eserlerin genellikle tezhip ve yaldızlarla süslü ilk } \\
\text { sayfaları için kullanılmıştır]. }\end{array}$ \\
\hline 103 & Rüstem رُسنتُّ R & Fars. \\
\hline 104 & رَفتّ Raf & Fars. $r e f>$ Ar. reff. \\
\hline 105 & Rahvan & Fars. $r \bar{a} h-v \bar{a} r '$ dan. \\
\hline 106 & Revani & Fars. revġani "çörek, poğaça"dan. \\
\hline 107 & Zirh & Fars. zirih - zirh. \\
\hline 108 & خَرْدَة Zerde & Fars. zerde. \\
\hline 109 & Zerdehan & Fars. \\
\hline 110 & 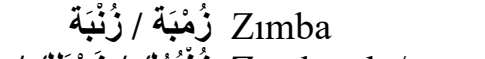 & Fars. sunbe'den. \\
\hline 111 & 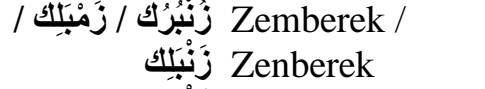 & Fars. zenbūrek "küçük top"tan. \\
\hline 112 & Zembil / Zenbil & Fars. zenbil-Ar. zinbil. \\
\hline 113 & 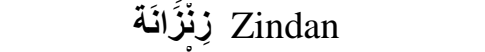 & Fars. zindān. \\
\hline 114 & Zinhar & Fars. zinhār - zinhar. \\
\hline 115 & Zivana & Fars. \\
\hline 116 & سَادَة Sade & Fars. sāde. \\
\hline 117 & ستَاطور Satır & Fars. sātūurr. \\
\hline 118 & سَبَت Sepet & Fars. seped-sebed. \\
\hline 119 & سِخْتِيَانَ Sahtiyan & Fars. sahtyān. \\
\hline 120 & سرَرَاي / سَرَايَة Saray & Fars. serāy. \\
\hline 121 & سَرْتَت Sert & Fars. serd. \\
\hline 122 & S Sֵرِْْوَال Şalvar & Fars. şelvār. \\
\hline 123 & سيُقَرَة & Fars. sufra. \\
\hline 124 & سنَمَافُور Semaver & Fars. semāver < Rus. samovar. \\
\hline 125 & س سِمْسَتَار Simsar & Fars. simsâr. \\
\hline 126 & Sincap & Fars. sincāb. \\
\hline 127 & سَنْطِير Santur & Fars. sanțur-sentūr. \\
\hline 128 & Süvari & Fars. suvār'dan suvāri. \\
\hline 129 & سيَيَة / سَبْيَةَة Sehpa & 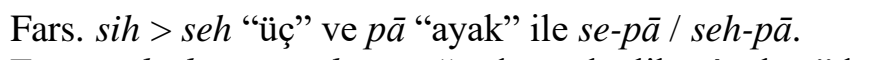 \\
\hline 130 & شََادِرْوَان Şadırvan & Fars. şādurbān > şādurvān "çadır, gölgelik, sâyeban"dan. \\
\hline 131 & شَال Şal & Fars. şāl $<$ Hint. \\
\hline 132 & شَكَاهِنْدَة Şahende & Fars. \\
\hline 133 & شَّاهِين Şahin & Fars. şāhin - şahin. \\
\hline 134 & Şَـhnaz & Fars. şehnaz. \\
\hline 135 & شَبَيَنَام Şebnem & Fars. şeb "gece" ve nem "yaşl1k" ile şeb-nem. \\
\hline 136 & شَخْشَبِير Çakşır & Fars. çākşūur. \\
\hline
\end{tabular}




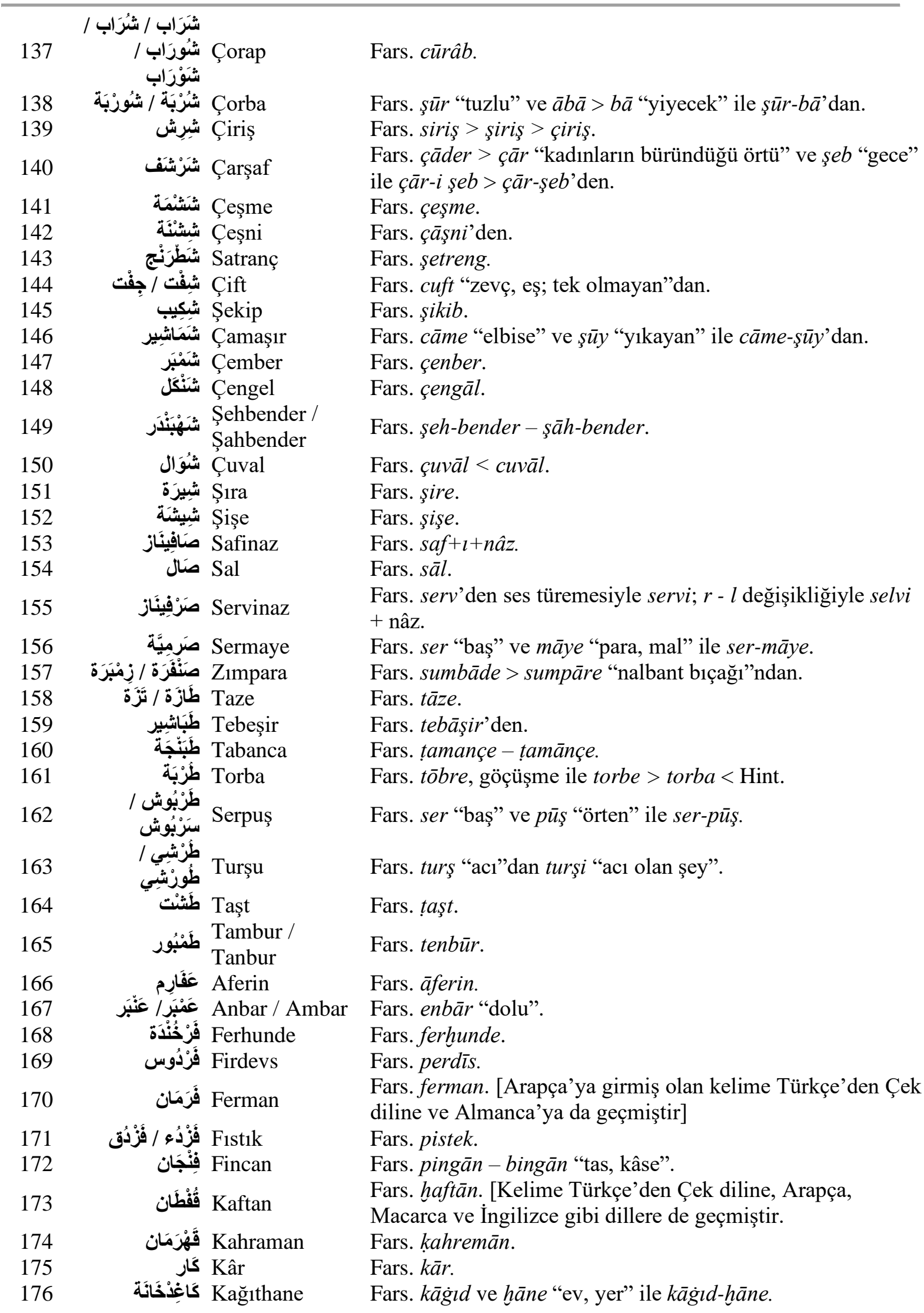




\begin{tabular}{|c|c|c|c|}
\hline 177 & كَبْثَثَة & Kepçe & Fars. kefçe. \\
\hline 178 & كِفْيَة & Kâhya & $\begin{array}{l}\text { Fars. ked-huda "ev işlerini yöneten kimse"den. [Kelime } \\
\text { Türkçe'den Arapça ve Balkan dillerine de geçmiștir]. }\end{array}$ \\
\hline 179 & كَرَار / كِرَار & Kiler & Fars. kilār'dan. \\
\hline & & & $\begin{array}{l}\text { Fars. kār "iş" ve hāne "ev, yer" > kār-h̆āne'den. Kelimenin } \\
\text { "kara" ve "hâne" kelimelerinden oluştuğu, "kara" }\end{array}$ \\
\hline 180 & كَرخَانَة & Kerhane & $\begin{array}{l}\text { kelimesinin Türkçede "kötü" anlamında kullanıldığ } 1 \text { ve } \\
\text { kelimenin "karahâne" yani "kötü ev, kötülük evi” anlamında } \\
\text { olduğu da söylenmiștir. }\end{array}$ \\
\hline 181 & كَرْدَان & Gerdan & Fars. gerden. \\
\hline 182 & كَرَسنَتَّة & Kereste & Fars. kerāste'den. \\
\hline 183 & كُسنبَة & Küspe / Küsbe & Fars. küsbe. \\
\hline 184 & كُسنتِيْر & Köstere & $\begin{array}{l}\text { Fars. küştere [Kelime Türkçe'den Arapça, Bulgarca ve } \\
\text { Sırpça'ya da geçmiştir]. }\end{array}$ \\
\hline 185 & كَثْنك & Köşk & Fars. $k \bar{u} s ̧ k-k u s ̧ k$ \\
\hline 186 & كَثِيَدة & Keşide & Fars. keşiden "çekmek"ten keşide. \\
\hline 187 & كُفْتَتَة & Köfte & $\begin{array}{l}\text { Fars. küften "ezmek, dövmek”ten küfte. [Kelime Türkçe’den } \\
\text { Arapça ve Balkan dillerine de geçmiştir]. }\end{array}$ \\
\hline 188 & كِلِيم & Kilim & $\begin{array}{l}\text { Fars. gilim. [Kelime Türkçe'den Balkan, Kafkas dillerine, } \\
\text { Arapça ve Rusça'ya da geçmiştir]. }\end{array}$ \\
\hline 189 & كَمَان & Keman & Fars. keman. \\
\hline 190 & كَمَر & Kemer & Fars. kemer. \\
\hline 191 & كِنَّار & Kenar & Fars. kenar. \\
\hline 192 & كنيف & Kenef & Fars. \\
\hline 193 & 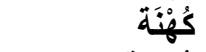 & Köhne & Fars. kuhne. \\
\hline 194 & كُوشَة & Köşe & Fars. gūşe > kūşe > köşe. \\
\hline 195 & لَِبْلاب & Leblebi & $\begin{array}{l}\text { Fars. leblebū. [Kelime Türkçe'den Arapça, Bulgarca, Sirpça } \\
\text { ve Yunanca'ya da geçmiştir]. }\end{array}$ \\
\hline 196 & مَارِسنتَّان & Maristan & $\begin{array}{l}\text { Fars. bimār "hasta" ve yer bildiren - } \\
\text { istān ile bimāristān > māristān }\end{array}$ \\
\hline 197 & مَازَة / مَزَّة & Meze & Fars. meze. \\
\hline 198 & مَاشَة & Maşa & Fars. māşe "kıskaç". \\
\hline 199 & 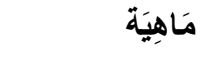 & Mahiye & Fars. māhi “ayla ilgili"den māhiyye. [Türkçe'de türetilmiştir]. \\
\hline 200 & مَأهِيتَاب & $\begin{array}{l}\text { Mehtap / } \\
\text { Mâhitab / } \\
\text { Mahtab }\end{array}$ & $\begin{array}{l}\text { Fars. } m \bar{a} h \text { "ay" ve } t \bar{a} b \text { " "şık, aydınlık" ile } t \bar{a} b-\imath m \bar{a} h \text { 'tan } m \bar{a} h- \\
t \bar{a} b>m e h t \bar{a} b\end{array}$ \\
\hline 201 & مَكُوك كُ & Mekik & Fars. mekik-mekūk. \\
\hline 202 & 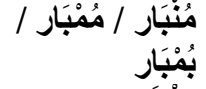 & $\begin{array}{l}\text { Munbar / } \\
\text { Mumbar }\end{array}$ & Fars. bunbar. \\
\hline 203 & مَنْطَش & Menteşe & Fars. bend-keşe’'den. \\
\hline 204 & مَهْهَتَات & Mehtap & $\begin{array}{l}\text { Fars. } m \bar{a} h \text { "ay" ve } t \bar{a} b \text { “1ş1k, aydınlık" ile } t a \bar{b} b-\imath m \bar{a} h \text { 'tan } m \bar{a} h- \\
t \bar{a} b>m e h t \bar{a} b \text {. }\end{array}$ \\
\hline 205 & مِهِزْدَار & Mühürdar & Fars. muhr ve $d \bar{a} r$ "sâhip ve mâlik" olan ile $m u h r-d \bar{a} r$. \\
\hline 206 & مِهْهِنْدَر & Mihmandar & $\begin{array}{l}\text { Fars. mihmān "misâfir" ve } d \bar{a} r \text { "sâhip ve mâlik olan" } \\
\text { ile mihmān-dār. }\end{array}$ \\
\hline 207 & 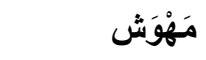 & Mehveş & Fars. māh > meh “ay"dan -veş ekiyle meh-veş. \\
\hline 208 & مُورِسنتَان & Mâristan & $\begin{array}{l}\text { Fars. bimā̄r "hasta" ve yer bildiren - } \\
\text { istān ile bimāristān > māristān. }\end{array}$ \\
\hline 209 & مِيس / مِيز & Mis & Fars. $m \bar{\imath} z$ 'den \\
\hline
\end{tabular}


Fars. Yiğitliği, cesâreti ve pehlivanlığı ile meşhur Şehnâme kahramanının adı olup Türkçede "yiğit, cesur, pehlivan" anlamında ve kadın ismi olarak kullanılmıştır. Fars. nāzuk'ten. Fars. nāzuk'ten.

Fars. nijād.

Fars. nigār .

Fars. nergis.

Fars. nārgil "Hindistan cevizi"nden nargile.

Fars. nerm "yumuşak" ve -in ekiyle nermin.

Fars. nāzuk >nāzik'ten nezaket. Form Türkçe'dir. [Arapça kelimelere benzetilerek Türkçe'de türetilmiştir].

Fars. nevşādur'dan nişādū $r>n i s ̧ a d ı r$.

Fars. nişan.

Fars. nişān ve yer bildiren -gāh ekiyle nişān-gāh

Fars. nikriz.

Fars. nânü'dan.

Fars. nihāl.

Fars. nev "yeni" ve $z \bar{a} d$ "doğmuş" ile nev-zād.

Fars.

Fars. nene.

Fars. hāan + Fars. zāden "doğmak; doğurmak”tan zade. hep (Kamu kelimesinin de aslı olan Fars. hamā $\dot{g}$ 'dan geldiği ileri sürülmektedir) ve Fars. yek "bir" ile hep yek.

Fars. har "eşek" ve gele "sürü"den har-gele.

Fars. humāyūn "hükümdara âit olan"dan [?].

Fars. endam.

Fars. huveydā.

Fars. $y \bar{a} f t e$ "tezkire, pusula".

Fars. yaver.

Fars. yahni "pişmiş, pişkin" [Kelime Türkçe'den Arapça, Bulgarca ve Sırpça'ya da geçmiştir]

Fars. $y a \dot{g} m \bar{a}-y \bar{a} \dot{g} m \bar{a}$.

Fars. yek "bir" ve yer bildiren -gāh ekiyle yek-gāh > yegâh.

\section{Farsça + Arapça Sözcükler}

Fars. $h \bar{o} s ̧+$ Ar. $\bar{A} d e m<\mathrm{I} b r$.

Fars. $m \bar{a} h i+$ Ar. $n \bar{u} r$.

\section{Farsça + Türkçe Sözcükler}


2

3

4

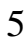

7

8

9

10

11

12

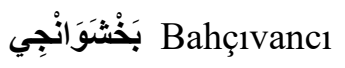

Pervazc1

Bostanc1

قَادِن بَمْبَة Pembe kadın

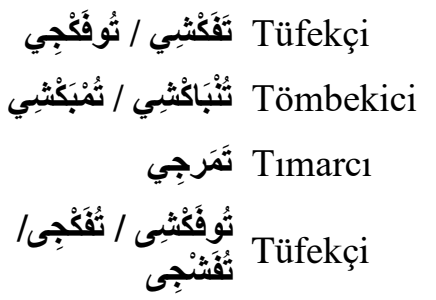

Çeşnici

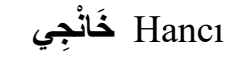

خُرْدَوَاتِي / حُجِي

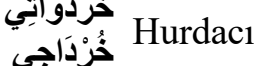
خَرْمَنْجِى Harmanc1 خَسْنََّْ دُبَش Dübeş Zirhç1 Zimbac1 سُفْرَجِي شُشْنَجِْي

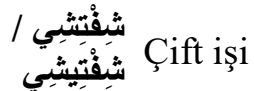
شَمَاثَشْرجِي Çamaşırc1 شُورَبْجِي

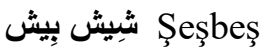
Sabuncu طُرْتَجِي

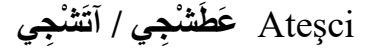
Anbarc1 / Ambarc1

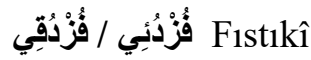
كَرَارْجِي
Fars. $b \bar{a} \dot{g} c ̧ e$ ve -bān ekiyle $b \bar{a} \dot{g} c ̧ e-b \bar{a} n$ 'dan $b \bar{a} \dot{g} c ̧ e-$ vān > bahçevan > bahçıvan. + Türk. -c1.

Fars. pervez'den + Türk. -ci.

Fars. būstān, $b \bar{u}$ "koku" ve yer bildiren -istān > sitān ekiyle $b \bar{u}$-sitān > būstān "koku yeri”. + Türk. -ci.

Fars. penbe "pamuk"tan (?)Eski Türk. kātūn <

Soğd. hầtūn < hāatēn.

Fars. tufeng + Türk. -ci.

Fars. tenbāk $\bar{u}<$ İtal. tabaco + Türk. -ci.

Fars. timār + Türk. -ci.

Fars. tufeng + Türk. -ci.

Fars. çāş̧ni "tat, lezzet" ve gir "tutan, alan" ile çāşni-gir.

Fars. çāşni "tat, lezzet" + Türk. -ci.

Fars. hăan + Türk. -ci.

Fars. hurde "yenilmiş şey, kırıntı" + Türk. -ci.

Fars. harmen - hirmen + Türk. -ci.

Fars. + Türk. geçişsiz f. (< hasta+lan-mak.

Fars. $d \bar{u}$ "iki" ve Türk. beş ile dü beş.

Fars. zirih - zirh + Türk. -çı.

Fars. sunbe + Türk. -c1.

Fars. sufra + Türk. -c1.

Fars. çāşsni + Türk. -ci.

Fars. cuft "zevç, eş; tek olmayan" + Eski Türk. $\iota s ̧+i$.

Fars. cāme "elbise" ve şūy "yıkayan" ile cāme-ş̧ūy' dan + Türk. -c1.

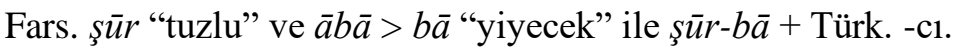

Fars. şeş "altı" ve Türk. beş ile şeş beş.

Fars. șābūn < Lat. sapo + Türk. -cu.

Fars. turşs "acı"dan turşi "acı olan şey" + Türk. -cu.

Fars. àteş $<$ Süry. + Türk. -çi.

Fars. enbār "dolu" + Türk. -c1.

Fars. fistık ve Türk. nispet eki -i ile fistıki.

Fars. kilār +Türk. -ci. 


\begin{tabular}{|c|c|c|}
\hline 30 & كِثْنك Keşkek & Fars. keşkek < keşk ve Türk. küçültme eki -ek. \\
\hline 31 & كَلَبْشُ Kelepçe & $\begin{array}{l}\text { Fars. kelābe "iplik çilesi" ve Türk. küçültme eki } \\
+c ̧ e \text { ile kelābe+çe'den. }\end{array}$ \\
\hline 32 & Kعَاتْجِي Kemanc1 & Fars. keman + Türk. -c1. \\
\hline 33 & كَنَجَْة Kemençe & Fars. kemān ve Türk. küçültme eki -çe ile kemān-çe'den. \\
\hline 34 & Sُكْنَجِي Köhneci & Fars. kuhne + Türk. -ci. \\
\hline 35 & Miralay & Fars. mir "bey, emîr" ve Türk. alay ile mir-i alay > mir-alay. \\
\hline 36 & Nazlı نَازْبِي / نَظْبِي & Fars. $n \bar{a} z+$ Türk. -11 \\
\hline 37 & Nişanc1 & Fars. nişan + Türk. -c1. \\
\hline 38 & Nevin & Fars. nev "yeni" ve Türk. -in ilgi ekiyle nevin. \\
\hline 39 & يَغْعَجِى Yağmaci & Fars. $y a \dot{a g} m \bar{a}-y \bar{a} \dot{g} m \bar{a}+$ Türk. -c1. \\
\hline \multicolumn{3}{|c|}{ 14. Farsça + Yunanca Sözcükler } \\
\hline 1 & Gülfidan & Fars. gul + Yun. phytane. \\
\hline \multicolumn{3}{|c|}{ 15. Fransızca Kökenli Sözcükler } \\
\hline 1 & Apolet & Fr. épaulette < épaul "omuz". \\
\hline 2 & Otel & $\begin{array}{l}\text { Fr. hôtel < Lat. hospitale "kimsesizler ve yolcular için barınak, } \\
\text { misâfirhâne". }\end{array}$ \\
\hline 3 & أوَنْطَة Avanta & $<$ Fr. avantage. \\
\hline 4 & بَابَور / وَابُور Vapur & $\begin{array}{l}\text { Fr. vapeur < Lat. vapor 'buhar"; bateau à vepeur'den } \\
\text { kisaltma. }\end{array}$ \\
\hline 5 & بَالْطُو / بَلْطُو Palto & Fr. paletot $<$ İng. \\
\hline 6 & بِرَسنتِِيج Prestij & Fr. prestige < Lat. prestigium "oyun, düzen, hîle". \\
\hline 7 & Bornoz & Fr. burnous $<$ Ar. burnus $<$ Yun. $<$ Lat. \\
\hline 8 & Prرِيزَة Perize / Berize & Fr. prise. \\
\hline 9 & ب بَكَكُنَة Balkon & Fr. balcon $<$ İtal. \\
\hline 10 & بَنْدُول Pandül & Fr. pendule $<$ Lat. \\
\hline 11 & بَنْسَة Pense & Fr. pincé. \\
\hline 12 & بَنْكِير Banker & Fr. banquier $<$ İtal. \\
\hline 13 & Polis & Fr. police < Lat. politia < Yun. politeia < polis "şehir". \\
\hline 14 & Pijama & Fr. pyjama $<$ İng. $<$ Fars. pāy-cāme "bacak elbisesi" $<$ Hint. \\
\hline 15 & Bere & Fr. béret $<$ Lat. \\
\hline 16 & Tül Tü T & Fr. tulle. [Fransa'da Tulle şehrinin adından]. \\
\hline 17 & تَنْنَنَ Tentene & Fr. dentelle. \\
\hline 18 & جَاز Gaz & Fr. gaz. [Lat. chaos'tan Van Helmont tarafindan türetilmiştir]. \\
\hline
\end{tabular}




\begin{tabular}{|c|c|c|}
\hline 19 & خَرْطُش Kartuş & Fr. cartouche $<$ İtal. \\
\hline 20 & دُوسيَيَة Dosya & Fr. dossier. \\
\hline 21 & Reyon & Fr. rayon. \\
\hline 22 & Seramik سِرَامِيك & Fr. céramique < Yun. \\
\hline 23 & شِفِرَة Şifre & Fr. chiffre < Lat. < Ar. șifr "sıfır". \\
\hline 24 & صَامُولَة Somun & Fr. saumon < Lat. \\
\hline 25 & Tarabiza & Fr. trapeze. \\
\hline 26 & Firkate / & İtal. fregata. \\
\hline 27 & فِ فَمَنْكُ Felemenk & Flaman. vlaming ve Fr. flameng'den. \\
\hline 28 & 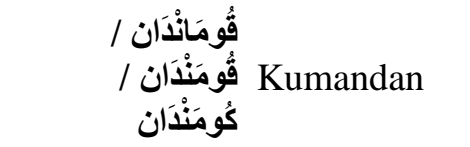 & Fr. commandant. \\
\hline 29 & كَابِل Kablo & Fr. câbleau - câblot $<$ Lat. \\
\hline 30 & كَابِيُوُ Kapüşon & Fr. capuchon $<$ İtal. \\
\hline 31 & 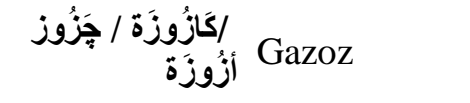 & Fr. gazeuse. \\
\hline 32 & كَانْتِين Kantin & Fr. cantine $<$ İtal. \\
\hline 33 & Kauçuk & Fr. caoutchouc < İsp. [Ekvator yerlilerinin dilinden]. \\
\hline 34 & كُبُود Kaput & Fr. capote. \\
\hline 35 & كُرْوكِي Kroki & Fr. croquis. \\
\hline 36 & كَثِْْير Kaşmir & Fr. cachemire < İng. [Keşmir yer adından]. \\
\hline 37 & / كُمُمَنَارِي /Komiser & Fr. commissaire < Lat. \\
\hline 38 & 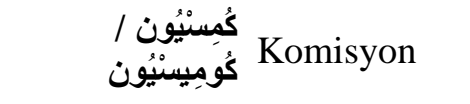 & Fr. commission < Lat. \\
\hline 39 & كَنَبَة Kanepe & Fr. canapé < Lat. < Yun. \\
\hline 40 & كُولِيرًا & $\begin{array}{l}\text { Fr. choléra }<\text { Lat. }<\text { Yun. [Kelime XIX. yüzyıl ortalarında } \\
\text { gazete aracıllğıyle Türkçe'ye geçmiştir]. }\end{array}$ \\
\hline 41 & Komisyoncu & Fr. commission < Lat. + Türk. -cu. \\
\hline 42 & Sonyak & Fr. cognac. [Fransa'da Cognac şehrinin adından]. \\
\hline 43 & مَارِيشَال Mareşal & Fr. maréchal < Alm. markhaskalk "at bakıcısı". \\
\hline 44 & نَفْتَالِين Naftalin & Fr. naphtaline < Yun. \\
\hline
\end{tabular}


16. Fransızca + Farsça Kökenli Sözcükler

17. Fransızca + Türkçe Kökenli Sözcükler

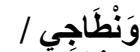

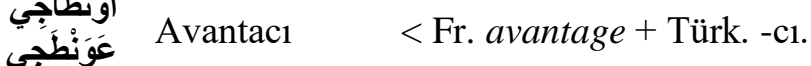

بَلْفِجى Valfçı $\quad$ Fr. valve $<$ Lat. + Türk. -ci.

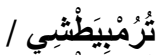

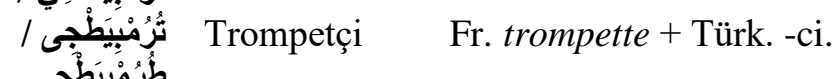

تَكْسَجْي $\quad$ Taksici $\quad$ Fr. taxi + Türk. -ci.

Telgrafç1

Fr. télégraphe < Yun. têle "uzak" ve graphe "yazmak" + Türk. -ci.

Fr. télévision + Türk. -ci.

\section{8. İbranice + Farsça Kökenli Sözcükler}

\section{9. İngilizce Kökenli Sözcükler}

$$
\begin{aligned}
& \text { فَنْجَري Fenceri İng. finger. }
\end{aligned}
$$

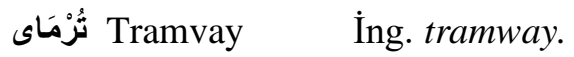

$$
\begin{aligned}
& \text { دَامْبَر } \\
& \text { Stepne İng. stepney. } \\
& \text { كِرَانْكُ Krank İng. crank. }
\end{aligned}
$$

\section{0. İspanyolca Kökenli Sözcükler}

$$
\text { كَنَرَيًَا } \text { Kanarya İsp. canario. }
$$

\section{1. İtalyanca Kökenli Sözcükler} İtal. scandiglio. 
6

9

10

11

12

13

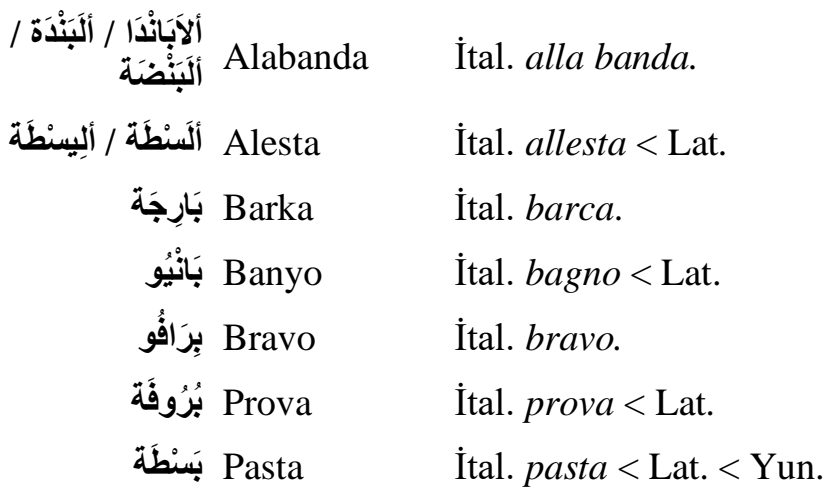

Amerika yerlilerinin dilinden İspanyolca aracıllı̆̆ıle çeşitli Avrupa dillerine geçen kelime Türkçe'ye İtalyanca ve Yunanca'dan girmiştir.

İtal. volta $<$ Lat.

İtal. posta $<$ Lat.

İtal. bussola.

İtal. politica $<$ Yun.

İtal. birra $<$ Alm. bier

İtal. tersana $<$

İtal. tocca < toccare "dokunmak, el s1kmak" < Lat.

İtal. teatro < Lat. $<$ Yun.

İtal. tela $<$ Lat.

$<$ İtal. ganzo.

İtal. giaveta.

İtal. dozzina < Lat.

İtal. timón.

İtal. ricetta.

İtal. aringa $<$ Alm.

İtal. zipon.

İtal. salata.

İtal. zupya.

İtal. dama.

İtal. tavola < Lat. tabula "tahta".

İtal. tappo.

İtal. tromba $>$ turumba $>$ tulumba. [Kelime Türkçe'den Farsça, Arapça ve Yunanca'ya da geçmiştir] 
غَنَدُور / غَنْدُورَة Kundura

İtal. condura < Yun. cothurne "Romalı artistlerin giydiği kayışlı çedik”. [Kelime Türkçe'den Arapça ve Sırpça'ya da geçmiştir].

İtal. fabbrica $<$ Lat.

İtal. falso < Lat.

İtal. flanella $<$ İng.

İtal. fogna.

İtal. fiocco.

İtal. corsaro.

İtal. carovana "gemi" + Tür. -c1.

İtal. calzino.

İtal. camara.

İtal. casino.

İtal. condura $<$ Yun. cothurne "Romalı artistlerin giydiği kayışlı çedik”. [Kelime Türkçe'den Arapça ve Sırpça'ya da geçmiştir].

İtal. colonia. [Köln (Cologne) şehrinin adından].

İtal. locanda "han, pansiyon" < Lat.

İtal. limonada < limone "limon".

İtal. mesura.

İtal. macchina $<$ Lat. $<$ Yun.

İtal. mobilia < Lat.) [Kelime önce İtalyanca'dan Türkçe'ye geçmiş, daha sonra Fransızca'dan möble şekli girmiştir; bugün daha çok mobilya kullanılmakla birlikte möble biçimi bâzı bölgelerde yaygındır].

ميدَالَِيَة Madalya İtal. medaglia $<$ Lat.

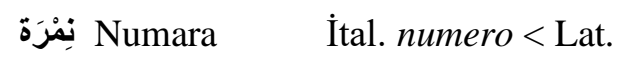

وَرْدِيَة

\section{2. İtalyanca + Türkçe Kökenli Sözcükler}

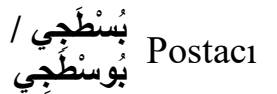

Tiyatrocu

Dümenci

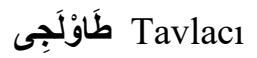

طُمْنَجِِى Tulumbac1
İtal. posta $<$ Lat. + Türk. -ci.

İtal. teatro $<$ Lat. $<$ Yun. + Türk. -ci.

İtal. timón + Türk. -ci.

İtal. tavola < Lat. tabula "tahta" + Türk. -c1.

İtal. tromba $>*$ turumba $>$ tulumba) [Kelime Türkçe'den Farsça, Arapça ve Yunanca'ya da geçmiştir] + Türk. -c1. 
6

بَالَة Pala
İtal. condura + Türk. -c1.

İtal. locanda "han, pansiyon" + Türk. -c1.

İtal. macchina $<$ Lat. $<$ Yun. + Türk. -c1.

\section{Latince Kökenli Sözcükler}

\section{Macarca Kökenli Sözcükler}

\section{Moğolca Kökenli Sözcükler}
أغًا / آقَا
Moğ. $\bar{a} k \bar{a}$ "ağabey".

جִ Ceylan

$<$ Moğ. cegeren > ceyran, aslan ve kaplan gibi kelimelerin etkisiyle ceylân) [Moğolca'dan doğrudan veya Farsça yoluyle Türkçe'ye giren kelime komşu dillere de geçmiştir]

\section{Moğolca + Farsça Kökenli Sözcükler}

\section{Portekizce Kökenli Sözcükler}

1

$$
\text { Pُبرْتُقَّال / بُرْنُقَّان Portakal }
$$

(Portekiz'in batı dillerindeki ismi olan Portugal adından) [Portekizli tüccarlar tarafindan XVI. yüzyılda Uzakdoğu'dan Avrupa'ya getirildiği için bu adı almıştır].

\section{Rumence Kökenli Sözcükler}

$$
\text { شَنْطَة }
$$

$<$ Rume. geanta [?].

\section{Slav Kökenli Sözcükler}

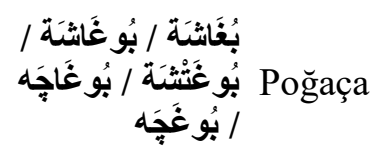

Slav. pogaça $<$ İtal. fogaccia. 


\begin{tabular}{|c|c|c|}
\hline \multicolumn{3}{|c|}{ 30. Türkçe Kökenli Sözcükler } \\
\hline 1 & Aktay & Türk. \\
\hline 2 & Altın & Eski Türk. altun; kökü kesin olarak belli değildir. \\
\hline 3 & Altınc1 & Türk. \\
\hline 4 & Kavurma & Türk. \\
\hline 5 & Kayış & Eski Türk. kad $l ı s$. \\
\hline 6 & آبَاظَة Abaza & Türk. \\
\hline 7 & Abla & Eski Türk. apa “yaşça büyük kızkardeş”ten [?]. \\
\hline 8 & Abi & Türk. \\
\hline 9 & Etek & Eski Türk. etek; kökü belli değildir. \\
\hline 10 & 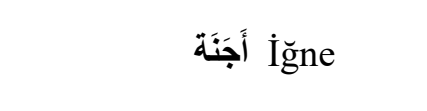 & $\begin{array}{l}\text { Eski Türk. yigne. [Kökü kesin olarak belli olmayan kelimenin } \\
\text { başındaki "y" sesi sonradan türemiştir] }\end{array}$ \\
\hline 11 & إخْتِيَار İhtiyar & $\begin{array}{l}\text { Türk. (Şemseddin Sâmi’ye göre Arapça sâhibü’l- } \\
\text { ihtiyar "seçme hakk1 elinde bulunan kimse" tamlamasından } \\
\text { kısaltma yoluyle ortaya çıkmış olmalıdır) [Eskiden galat } \\
\text { sayıldığg için bunun yerine koca kelimesi kullanılırdı] }\end{array}$ \\
\hline 12 & Karagöz & 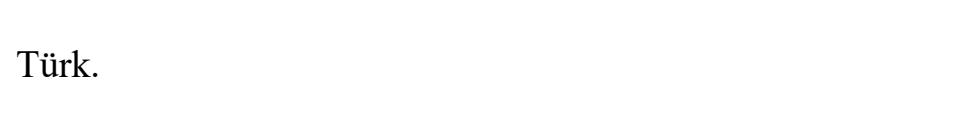 \\
\hline 13 & / قرَافُقُش أَرَعُوش Karakuş & Türk. \\
\hline 14 & Ordu & $\begin{array}{l}\text { Eski Türk. ordu "karargâh, hâkānın oturduğu şehir" < } \\
\text { Moğ. orda. }\end{array}$ \\
\hline 15 & أرْدُخَانَة Orduhane & $\begin{array}{l}\text { Eski Türk. ordu "karargâh, hâkānın oturduğu şehir" < } \\
\text { Moğ. orda. + Fars. ḩāne "ev, yer". }\end{array}$ \\
\hline 16 & 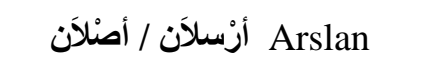 & Eski Türk. arslan. \\
\hline 17 & 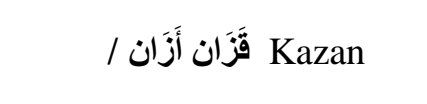 & 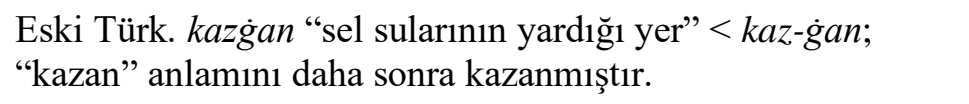 \\
\hline 18 & Özbek & Türk. \\
\hline 19 & Kazma & Türk. \\
\hline 20 & Köstek & $\begin{array}{l}\text { Türk. < köste-k; köste-mek fiili halk ağzında "hayvanın } \\
\text { ayaklarını iple bağlamak" anlamında kullanılır. }\end{array}$ \\
\hline 21 & Eski & Eski Türkçe'den beri kullanılır. \\
\hline 22 & أنثْنَكَ & Türk. \\
\hline 23 & Eşkin & Eski Türk. eşkin < eş-mek "koşmak". \\
\hline 24 & 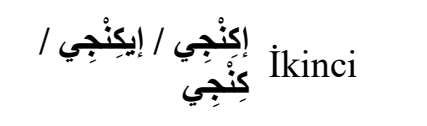 & $\begin{array}{l}\text { Eski Türk. ikki } \\
+ \text { nci. }\end{array}$ \\
\hline
\end{tabular}




\begin{tabular}{|c|c|c|c|}
\hline 51 & بَاغ / بَاغَة & Bağ / Bağa & Eski Türk. $b \bar{a} \dot{g}<b \bar{a}-m a k$ "bağlamak". \\
\hline 52 & 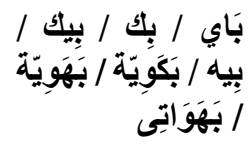 & Bey & Eski Türk. beg. \\
\hline 53 & بُبُن / بُوتُنُ & Bütün & Eski Türk. büt-mek “ sona ermek”ten büt-ü-n. \\
\hline 54 & بَرَدَاق & Bardak & $\begin{array}{l}\text { Orta Türk. [Oğuzca] bart "su içilen kap"tan küçültme } \\
\text { ekiyle bart+ak. }\end{array}$ \\
\hline 55 & بَرَدْوُو / بَرْضُو & $\begin{array}{l}\text { Bir de / Bir } \\
\text { daha / Bir dahi }\end{array}$ & $\begin{array}{l}\text { Eski Türk. bir + Eski Türk. takl, tak-mak'tan zarf-fiil ekinin } \\
\text { kalıplaşmasıyle tak-ı }>\text { dakl }>\text { dag் }>>d a h ı>d a h i>d a .\end{array}$ \\
\hline 56 & بُبرْغُل & $\begin{array}{l}\text { Burgul / } \\
\text { Bulgur }\end{array}$ & $\begin{array}{l}\text { Türk. [Kelime Türkçe'den bulg̈ur ve burg̈ul şekillerinde } \\
\text { komşu dillere de geçmiştir]. }\end{array}$ \\
\hline 57 & بُرْغِي / بَرَاغِى & Burgu & Türk. \\
\hline 58 & بَبَرْنَقَق / بَارْمَق / & Parmak & $\begin{array}{l}\text { Türk. < barmak) [XIII. yüzyıldan îtibâren kullanılmaya } \\
\text { başlanmıştır; Eski Türkçe'de parmağa eñek deniyordu]. }\end{array}$ \\
\hline 59 & بُرْمَه / بُوزْمَة & Burma & Eski Türk. bür-me "büzme". \\
\hline 60 & 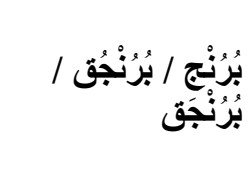 & $\begin{array}{l}\text { Bürümcük / } \\
\text { Bürüncük / } \\
\text { Bürümcek / } \\
\text { Bürüncek }\end{array}$ & $\begin{array}{l}\text { Türk. < bürü-n+cük - bürü- } n+c e k, n \sim \\
m \text { değişikliğiyle bürüm }+ \text { cük }- \text { bürüm }+ \text { cek. }\end{array}$ \\
\hline 61 & بَرُوعَتَب & Beri-Öte & $\begin{array}{l}\text { Eski Türk. berü; kökü kesin olarak belli değildir + Eski } \\
\text { Türk. öte, öt-mek “geçmek, saplanmak, yarıp içine girmek"ten } \\
\text { zarf - fiil ekinin kalılaşmasıle öt-e. }\end{array}$ \\
\hline 62 & برِيْجِي & Birinci & Eski Türk. $<b i r+i+n c i$. \\
\hline 63 & بُزْقق & Bozuk & Türk. $<b o z-u-k$ \\
\hline 64 & 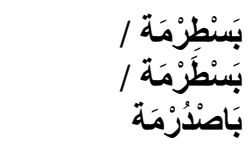 & Pastırma & $\begin{array}{l}\text { Türk. bastır-mak'tan fiil ismi ekinin kalıplaşmasıyle bastır- } \\
\text { ma. }\end{array}$ \\
\hline 65 & 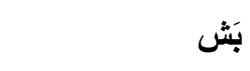 & Beş & Eski Türk. biş. \\
\hline 66 & بَتَثْقَة & Başka & Türk. < baş+ka [?]. \\
\hline 67 & بِثْلة & Beşli & $\begin{array}{l}\text { Eski Türk. biş } \\
+ \text {-li. }\end{array}$ \\
\hline 68 & 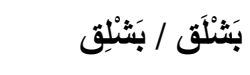 & Başlık & Eski Türk. $b \bar{a} s ̧+-11 k$. \\
\hline 69 & بِشِنْجَانَة & Çingene & Türk. < çingāne. \\
\hline 70 & بَتَنْنِجِ & Beşinci & Eski Türk. biş. < beş $+i+n c i$. \\
\hline 71 & بَصنمَة & Basma & Türk. \\
\hline 72 & بَصْنَجِي & Basmac1 & Türk. \\
\hline 73 & بَطَحْجِي & Batahcı & Türk. \\
\hline 74 & بَغَهَه / بَاغَه & Bağa & Eski Türk. bāka "kurbağa". \\
\hline
\end{tabular}




\begin{tabular}{|c|c|c|}
\hline 75 & بَفْرَة Bafra & Türk. \\
\hline 76 & Baklava & $\begin{array}{l}\text { E. T. Türk. baklagiu; kökü belli değildir. [Türkçe bir türev } \\
\text { olduğu anlaşllan kelime Arapça'ya ve Balkan dillerine de } \\
\text { geçmiştir]. }\end{array}$ \\
\hline 77 & 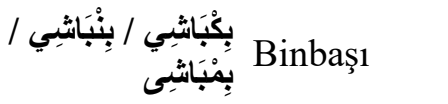 & Eski Türk. bing $>$ Orta Türk. ming $>$ biñ + Eski Türk. $b \bar{a} s ̧+1$. \\
\hline 78 & Bakraç بَكْرَج / بَقْرَاج Ba & Türk. bakır'dan küçültme ekiyle bakır+aç. \\
\hline 79 & بعكِمِز / بَكَمِيز Pekmez & Orta Türk. [Oğuzca] bekmes > pekmes < Fars. begmāz. \\
\hline 80 & بَلْطَة Balta & Eski Türk. baltu > baldu. \\
\hline 81 & Baltac1 بَلْطِجِي & Eski Türk. baltu > baldu + Türk. -ci. \\
\hline 82 & 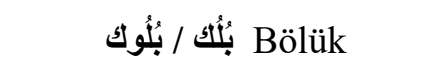 & Türk. $<b \ddot{l} l-\ddot{u}-k$. \\
\hline 83 & Boyun bağ1 & $\begin{array}{l}\text { Boyun: Eski Türk. boyın. Bağ: Eski Türk. bāg }<b \bar{a}- \\
\text { mak"bağlamak". (Bir nesneyi saran şey, sarg1). }\end{array}$ \\
\hline 84 & Biniş بِش B & Türk. < bin-iş. \\
\hline 85 & Boyac1 & Türk. \\
\hline 86 & Bُوِِى Boru & Eski Türk. borgiuy. \\
\hline 87 & 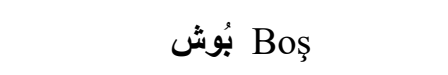 & Eski Türk. $b \overline{o s s . ~}$ \\
\hline 88 & بُوص Pusu & $\begin{array}{l}\text { Eski Türk. busuğ > E. T. Türk. busu < bus-mak "pusuya } \\
\text { yatmak". }\end{array}$ \\
\hline 89 & Boğaz & Eski Türk. bog் $u z<b o \breve{g}-u-z$. \\
\hline 90 & 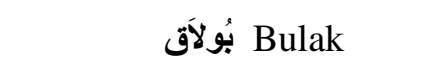 & Eski Türk. \\
\hline 91 & Boya & $\begin{array}{l}\text { Eski Türk. bodud } \dot{g}<\text { bodu-mak "boyamak", } \underline{d} \sim y \text { gelişimi ve } u \\
\sim a \text { değişimiyle boya. }\end{array}$ \\
\hline 92 & Bayrak & $\begin{array}{l}\text { Eski Türk. batrak "ucuna bir ipek parçası takılan mızrak" } \\
{[<\text { batır-ak] > badrak> badrak > bayrak. }}\end{array}$ \\
\hline 93 & بiz Biz & Çağatay. bigiz. \\
\hline 94 & Beş بِيش & Eski Türk. biş \\
\hline 95 & بeşlik & Eski Türk. biş + Türk. -lik. \\
\hline 96 & Buyrultu / & Türk. < buyurul-tu. \\
\hline 97 & تَبَة & Eski Türk. töpü > *töpe > tepe; kökü belli değildir. \\
\hline 98 & Tetik & Eski Türk. \\
\hline 99 & تُشُن Tütün & Eski Türk. tütün "duman” < tüt-mek. \\
\hline 100 & Tütüncü & Eski Türk. tütün "duman" < tüt-mek + Türk. -ci. \\
\hline 101 & Terelelli & Türk. ses taklidi k. \\
\hline 102 & 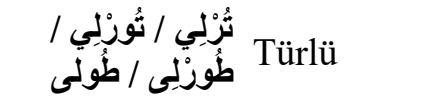 & Eski Türk. türlüg. \\
\hline
\end{tabular}




\begin{tabular}{|c|c|c|}
\hline 103 & Tirnak & Eski Türk. tırngak. \\
\hline 104 & Tozluk & Eski Türk. $t \bar{o} z+$ Türk. -lık. \\
\hline 105 & Tatl1 تَظِِْي / طَطْبِي & 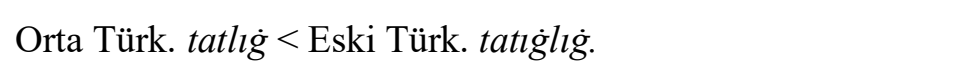 \\
\hline 106 & تָ Tek & Eski Türk. tek. \\
\hline 107 & تَكَنَة & Eski Türk. tekne; kökü belli değildir. \\
\hline 108 & Terlik & Türk. ter'den ter+lik. \\
\hline 109 & تِيزَة Teyze & $\begin{array}{l}\text { Türk. tag } \bar{a} y>\text { tay "dayı" ve eze "büyük kı kardeş" ile tay } \\
\text { eze+si }>\text { *tayaza > *teyeze > teyze. }\end{array}$ \\
\hline 110 & Timur & Türk. \\
\hline 111 & جَاوِيش / شَدَاوِش Çavuş & Eski Türk. çavuş "birlik komutanı”. \\
\hline 112 & Giritli & Türk. \\
\hline 113 & Ayakkabıc1 & Türk. < çiz-me $[c ̧ o ̈ z-m e]+-c i$. \\
\hline 114 & T جَزْمَة / جِزْمَة & Türk. < çiz-me [çöz-me] \\
\hline 115 & جَثْنْمَة Geçme & Eski Türk. keç-mek'den. \\
\hline 116 & C جَفَالِكِ / شَفْلْكِ Ciftlik & Türk. < çift+lik "Bir çift öküzle bir yılda sürülen toprak". \\
\hline 117 & جلا جَلا & Türk. gel-mek’ten istek ekinin kalıplaşmasıyle gel-e. \\
\hline 118 & 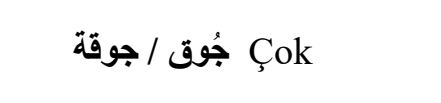 & $\begin{array}{l}\text { Eski Türkçe'de geçmez, ilk defa Hârezm Türkçesi'nde ortaya } \\
\text { çımıştır. }\end{array}$ \\
\hline 119 & جִiş & Türk. Ses taklidi k. \\
\hline 120 & 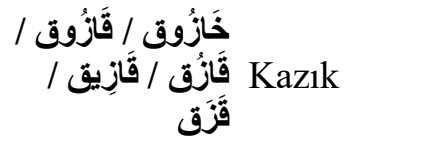 & Eski Türk. kaznguk. \\
\hline 121 & خَرَْخَنَة Kargaşa & $\begin{array}{l}\text { Eski Türk. kargaş-mak "lânetleşmek, kavga etmek"ten kargaş- } \\
\text { a. }\end{array}$ \\
\hline 122 & دَاغ Dağ & Eski Türk. $t \bar{a} \dot{g}$. \\
\hline 123 & Dipçik & Türk. $<d i p+c ̧ i k$. \\
\hline 124 & درُْنتجنجي Dördüncü & Türk. < dört+ü+ncü. \\
\hline 125 & مَرْدَشَة Dertleşmek & Türk. $<$ dert+leş-mek $<$ dert+le-ş-mek. \\
\hline 126 & درِيك Direk & $\begin{array}{l}\text { Eski Türk. tirek < tire-mek "destekleyerek dikmek, dik } \\
\text { tutmak". }\end{array}$ \\
\hline 127 & دُشَمَة Döşeme & Eski Türk. töşse-mek’ten. \\
\hline 128 & 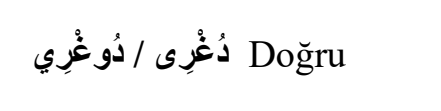 & $\begin{array}{l}\text { Eski Türk. tog்ru - tog்uru < tog்ur-mak "bir şeye doğru } \\
\text { yönelmek". }\end{array}$ \\
\hline 129 & دَقَقِمْ Değirmi & Eski Türk. tegirme - tegirmi < *tegir-mek "döndürmek". \\
\hline
\end{tabular}




\begin{tabular}{|c|c|c|}
\hline 130 & Tokmak & Eski Türk. tokımak. \\
\hline 131 & دُلُمَة / ضُلْمَة Dolma & Eski Türk. tōl-mak’tan. \\
\hline 132 & دَمَجَانَة Damacana & Türk. $<$ damıcana $<$ İtal. damigiana. \\
\hline 133 & دمِرِ Demir & Eski Türk. temür $>$ demür $>$ demir. \\
\hline 134 & Demirtaş دِمِرْدَاش D D & Türk. \\
\hline 135 & دَمَفَة Damga & Eski Türk. tamġa "mühür". \\
\hline 136 & Dondurma & Türk. < don-dur-mak'tan. \\
\hline 137 & Duvak دُوَاء / دُوَاق & 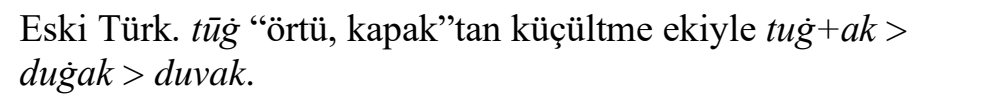 \\
\hline 138 & Deveci & $\begin{array}{l}\text { Eski Türk. teve - tevey (teve'nin Moğolca temegen'den geldiği } \\
\text { bâzı dilciler tarafindan ileri sürülmüştür) + Türk. -ci. }\end{array}$ \\
\hline 139 & دَوْزنَن Düzen & Türk. < düz-en [?] \\
\hline 140 & 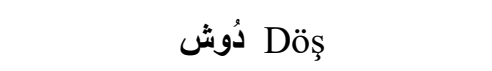 & Eski Türk. tō̄s “göğüs kemiği”". \\
\hline 141 & دُوشَكَك Döşek & Türk. < döşe- $k$, Eski Türk. töşek < töşe-mek. \\
\hline 142 & دُوقُزْنْجِي Dokuzuncu & Türk. $<$ dokuz $+u+n c u$. \\
\hline 143 & دُؤلْمَة / ضُلْمَة Dolma & Eski Türk. tōl-mak. \\
\hline 144 & دُونَنْمَة Donanma & $\begin{array}{l}\text { Türk. < dona-n-mak, Eski Türk. tonan-mak }<\text { ton }+a-n-m a k< \\
\text { ton "elbise"den. }\end{array}$ \\
\hline 145 & دِيز Diz & Eski Türk. tiz. \\
\hline 146 & Arslan & $\begin{array}{l}\text { Eski Türk. arslan; köküyle ilgili olarak çeşitli görüşler ileri } \\
\text { sürülmüştür. }\end{array}$ \\
\hline 147 & Sokak & $\begin{array}{l}\text { Türk. (Arapça birtakım kaynaklarda kelimenin Türkçe olduğu } \\
\text { ifade edilirken, Türkçe bazı kaynaklarda ise Arapça kökenli } \\
\text { olduğu söylenmektedir]. }\end{array}$ \\
\hline 148 & 染 Zemalik / & Eski Türk. üzüm < ̈̈z-mek "kesmek, koparmak" + -lük. \\
\hline 149 & Z1mbırt1 زِمْبِلِيَة & Türk. zımbır $+t \imath$. \\
\hline 150 & ستَاقِ Sak1z & Eski Türk. sag̀gz - saklz. \\
\hline 151 & سنَاقِزْلِي Sak1zl1 & Eski Türk. sagiglz - saklz + -l1. \\
\hline 152 & Saçak & Türk. saç "kıl"dan küçültme ekiyle $s a c ̧+a k$. \\
\hline 153 & سنَجْنَ Sürgün etmek & Türk. \\
\hline 154 & سَرْكِى Sergi & Türk. \\
\hline 155 & سِكِتِر Siktir & Türk. \\
\hline 156 & 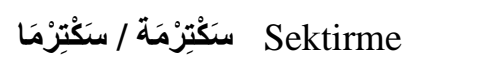 & Türk. < sek-tir-mek'ten. \\
\hline 157 & 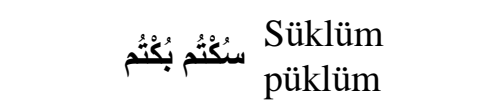 & $\begin{array}{l}\text { Türk. bükül-mek’ten bükül-ü-m > büklüm ve anlamı } \\
\text { güçlendiren tekrar kelimesi süklüm ile yapılmış olabilir. }\end{array}$ \\
\hline
\end{tabular}




\begin{tabular}{|c|c|c|}
\hline 158 & Sekizinci & Eski Türk. sekkiz - sekiz. < sekiz+i+nci. \\
\hline 159 & Sancak & Eski Türk. sānç-mak "saplamak"tan > sanç-ak > sancak. \\
\hline 160 & سَنْجَقْار Sancaktar & Türk. sancak’tan Fars. dār "tutan" ile sancak-dār. \\
\hline 161 & سُونْكِي / سُنْجَة & Eski Türk. süngü. \\
\hline 162 & شََادِر Çadır & $\begin{array}{l}\text { Eski Türk. çātır; Farsça çāder'den veya Türkçe çat- } \\
\text { mak fiilinden. }\end{array}$ \\
\hline 163 & 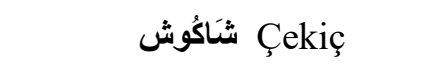 & Eski Türk. çekük-çeküş. \\
\hline 164 & شَاوَرْمَة & Eski Türk. çevür-mek’ten. \\
\hline 165 & 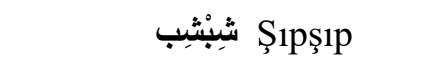 & Türk. ses taklidi k. \\
\hline 166 & شُبُّك Çubuk & Eski Türk. çıp "ince dal"dan $c ̧ ı p+l+k>c ̧ ı-b u k>c ̧ u b u k$. \\
\hline 167 & شُبُكُثِبي Çubukcu & Eski Türk. çıp "ince dal"dan $c ̧ \iota p+\imath+k>c ̧ \iota-b u k>c ̧ u b u k+-c u$. \\
\hline 168 & شُرُكُ Çürük & Türk. < çürü-k. \\
\hline 169 & شُرِيك & Orta Türkçe'den beri kullanılır; kökü belli değildir. \\
\hline 170 & شِش Şiş & Eski Türk. sīş. \\
\hline 171 & 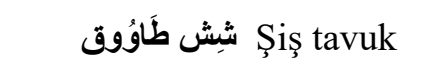 & Eski Türk. sī̧̧ + Eski Türk. takıg் $u>$ Orta Türk. takag்u. \\
\hline 172 & شِش كَبَاب Şiş kebap & Eski Türk. sīş + Ar. kebāa. \\
\hline 173 & شِشْبْرِكَك Şişbörek & Eski Türk. sīş + börek. \\
\hline 174 & شُشََْْانَة S Şişhane & Eski Türk. sīş + Fars. hāane. \\
\hline 175 & شَقَفَبَاظ Şaklaban & Türk. \\
\hline 176 & شَكَلَّمَة SSekerleme & Türk. < şeker+le-mek’ten. \\
\hline 177 & شُكَمَة & $\begin{array}{l}\text { Türk. Orta Türkçe'den beri kullanılır; bâzı dilcilere göre Eski } \\
\text { Türk. taşılk-mak> tışık-mak "dışarı çıkmak" fiilinden } \\
\text { gelmiştir. }\end{array}$ \\
\hline 178 & شُكَعْجِيه & Türk. <çek-me+ce. \\
\hline 179 & شُكَبِي & $\begin{array}{l}\text { Eski Türkiye Türkçesi’nde "efendi, sâhip; Rab, Tanrı" } \\
\text { anlamlarına gelen çalap kelimesinin ça-labı şekli de } \\
\text { vardır; çelebi bu ikinci şekilden gelmiş olmalıdır }\end{array}$ \\
\hline 180 & شِلِيك Çilek & $\begin{array}{l}\text { Türk. < çiğelek) [Türkiye Türkçesi’nde ortaya çıkmış olup } \\
\text { kökü tartışmalıdır]. }\end{array}$ \\
\hline 181 & شَمَطَة / شَمَاطَة & Türk. \\
\hline 182 & شَفَنْدُورَة SSamandıra & Türk. $<$ şamandura $<$ Yun. tsamadoura. \\
\hline 183 & شَçüüncü & Türk. < $\ddot{u c ̧}+\ddot{u}+n c \ddot{u}$. \\
\hline 184 & شَنْدِي S Şimdi & Türk. < uş imdi. \\
\hline 185 & شُوَزَة & Türk. çevir-mek'ten zarf-fiil ekinin kalıplaşmasıyle çevir-e. \\
\hline 186 & 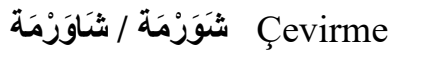 & Eski Türk. çevür-mek'ten. \\
\hline 187 & شُوْمَة Çomak & Türk. \\
\hline
\end{tabular}




\begin{tabular}{|c|c|c|}
\hline 188 & شُشيت Çit & Türk. \\
\hline 189 & Şiş شِيش Ş & Eski Türk. sīş. \\
\hline 190 & شِيَلَة بِيَّة Şöyle böyle & Türk. $<s ̧ u+i l e+b u+i l e$. \\
\hline 191 & صـاج Sac & Türk. \\
\hline 192 & صَاع قُولَاغَاسبي Sağ kolağas1 & Türk. birleşik $i$. \\
\hline 193 & صَاغ Sağ & Türk. \\
\hline 194 & Sağ salim & $\begin{array}{l}\text { Orta Türk. [Oğuzca] sāg }+ \text { Ar. selāmet "kurtulmak, sağlıklı } \\
\text { olmak"tan sālim. }\end{array}$ \\
\hline 195 & Sarmac & Türk. sarma $+c$. \\
\hline 196 & صرَمْةَة Sarma & Eski Türk. saru-mak'tan. \\
\hline 197 & 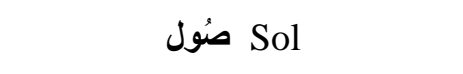 & Eski Türk. sōl. \\
\hline 198 & ضَايَنْ Dayan & Türk. \\
\hline 199 & طَبَان Taban & Eski Türk. taban. \\
\hline 200 & Tepsi & Eski Türk. tevsi < Çin. \\
\hline 201 & Tُبُق Topuk & Eski Türk. topık. \\
\hline 202 & 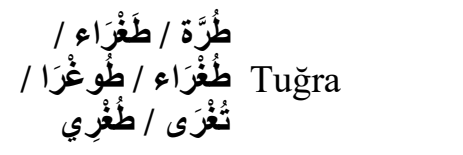 & $\begin{array}{l}\text { Orta Türk. [Oğuzca] tuġrag. [Kelime țugrāa olarak Arapça ve } \\
\text { Farsça'ya da geçmiş ve bu şekliyle Osmanlı Türkçesi’nde de } \\
\text { kullanılmıştır]. }\end{array}$ \\
\hline 203 & طُ Toz & Eski Türk. tōz. \\
\hline 204 & طَسنلاً /طَنْلَق Taslak & Türk. < tasla-k. \\
\hline 205 & طُ Tuz & Eski Türk. $t \bar{u} z$. \\
\hline 206 & طَقٌْ Takım & Türk. < tak-ı-m. \\
\hline 207 & طَنْطَنَة Tantana & Türk. [Bazı kaynaklarda Arapça olduğu söylenmiştir]. \\
\hline 208 & طُوَْجِي Topçu & Eski Türk. tōp + -çu. \\
\hline 209 & طُوََْْانَة Tophane & Eski Türk. top ve Fars. hāne “ev, yer" ile top-hāne. \\
\hline 210 & A عَرَبَبَة / آرَبَة / Araba & $\begin{array}{l}\text { Kökü kesin olarak belli değildir. [Muhtemelen Türkçe olan } \\
\text { kelime 'araba (عربه) imlâsiyle Arapça'ya geçmiş ve Osmanlı } \\
\text { Türkçesi metinlerinde bu imlâ ile de kullanılmıştır; ayrıca } \\
\text { Kafkas ve Balkan dillerine ve Rusça'ya da girmiştir]. }\end{array}$ \\
\hline 211 & Arabac1 & Türk. $a r a b a+-c l$. \\
\hline 212 & Arabahane & Türk. araba + Fars. hāne. \\
\hline 213 & 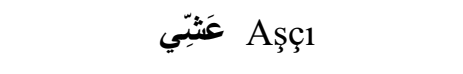 & Eski Türkçe. aş + -çı. \\
\hline 214 & Allak Bullak & $\begin{array}{l}\text { Türk. < alak bulak < Moğ. alag } \text {-bulag "alaca bulaca, karış1k } \\
\text { renkli”" }\end{array}$ \\
\hline 215 & Antepli & Türk. \\
\hline 216 & غُرَبِيَة / كُرَابِيَة Kurabiye & Türk. < gurābiyye. [Türkçe'de türetilmiş olmalıdır] \\
\hline
\end{tabular}




\begin{tabular}{|c|c|}
\hline 217 & Furça \\
\hline 218 & Firnn \\
\hline 219 & قََدِن Kadın \\
\hline 220 & Kaşık \\
\hline 221 & قََط / كَاط Kat \\
\hline 222 & قََاوُوق Kavuk \\
\hline 223 & قَاوُون / قَاوُونَة Kavun \\
\hline 224 & Kقُبرُصنِلي Kibrislı \\
\hline 225 & مَبَو كَتْفُلَا Kap1kethüdas1 \\
\hline 226 & مََرَامِيدَان \\
\hline
\end{tabular}

Türk.

Türk. < furun < Yun. phournos.

Eski Türk. kātūn $<$ Soğd. hătūun $<\underline{\text { hat }} \bar{t} \bar{n} n$

Eski Türk. kaşuk < kaşı-mak [ kaşa-mak] "yontmak". [Kelime Bulgarca, Sırpça ve Farsça gibi komşu dillere de geçmiştir].

Türk.

Eski Türk. kavuk "mesâne”. [Kelime Arapça, Macarca ve Sırpça'ya da geçmiştir].

Eski Türk. kāgīun.

Türk. Kıbrıs +11.

Eski Türk. kapı $\dot{g}>$ Orta Türk. kapug $>k a p u>k a p \imath+$

Fars. ked > ket "ev" ve hudā" "sâhip" ile ked-hudā

قََََان Kazan

Eski Türk. kazg்an "sel sularının yardığ yer" < kaz-g̈an;

"kazan" anlamını daha sonra kazanmıştır. [Kelime Farsça'ya, Balkan ve Slav dillerine de geçmiştir].

228

Kazanc1

Eski Türk. kazg்an + -c1.

Kizak

Türk.

Eski Türk. kaznguk.

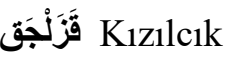

232

$$
\text { Gı }
$$

Kişla / Kişlak قََلاوُوظ<smiles>[14CH3]</smiles>

Kolluk

Kamç Kَثَة

Kamمَشَْجِي

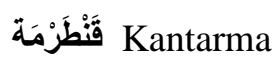

Kamış
Türk. < klzıl $+c \imath k$.

Kökü belli değildir. [Türkiye Türkçesi'nde XIV. yüzyıldan îtibâren görülür].

Eski Türk. kışlag < kışla-mak.

Eski Türk. kulābuz > kulāvuz.

Türk. Lehçelerde kullanılan kalıp "kapak, örtü"den küçültme ekiyle kalıp+ak. [Kelime Bulgarca, Sırpça, Yunanca, Macarca, Rusça, Arapça ve Farsça gibi komşu dillere, ayrıca Avrupa dillerine de geçmiştir.

Türk. $k o l+$ luk.

Eski Türkçe'den beri kullanılır; Eski Türkçe'de at, boğa ve devenin erkeklik organına verilen kamçı adıyla ilgili olabilir.

Türk. kamçı +-c1.

Türk. kantar-mak "su vermek, su içirmek; atın başını bağlamak"tan fiil ismi ekinin kalıplaşmasıyle kantar-ma.

Eski Türkçe'den beri kullanılır. [Kelime komşu dillere de geçmiştir]. 


\begin{tabular}{|c|c|c|}
\hline 241 & قََهْوَة Kahve & Türk. [Kelime Türkçe'den Avrupa dillerine de geçmiştir]. \\
\hline 242 & Kaطهْوَجِي Kahveci & Türk. < kahve + -ci. \\
\hline 243 & Koçağası & $\begin{array}{l}\text { Orta Türk. [Oğuzca] koç< koçngar) [Kelime Farsça, Macarca } \\
\text { ve Moğolca'ya da geçmiştir] + Moğ. } \bar{a} k \bar{a} \text { “ağabey”) [Kelime } \\
\text { batı dillerine ve } \bar{a} \dot{g} \bar{a} \text { şeklinde Arapça ve Farsça'ya da } \\
\text { geçmiştir] + s1. }\end{array}$ \\
\hline 244 & Kol & Eski Türk. \\
\hline 245 & Kolağas1 & $\begin{array}{l}\text { Eski Türk. } k o l+\text { Moğ. } \bar{a} k \bar{a} \text { "ağabey") [Kelime bat1 dillerine } \\
\text { ve } \bar{a} \dot{g} \bar{a} \text { şeklinde Arapça ve Farsça'ya da geçmiştir] + s1. }\end{array}$ \\
\hline 246 & فََْْمَق Kaymak & Eski Türk. kayak. \\
\hline 247 & S كَارْتَة & Türk. \\
\hline 248 & كَاكَة Kaka & Türk. ses taklidi k. \\
\hline 249 & 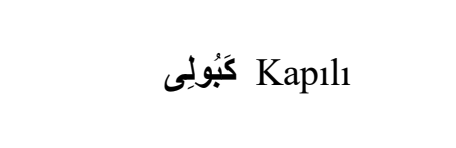 & $\begin{array}{l}\text { Eski Türk. kapig }>\text { Orta Türk. kapug }>k a p u>k a p ı<k a p-m a k \\
(\sim \text { kapa-mak) }) \text { [Kelime Arapça, Farsça ve Balkan dillerine de } \\
\text { geçmiştir] }+-1 \text {. }\end{array}$ \\
\hline 250 & 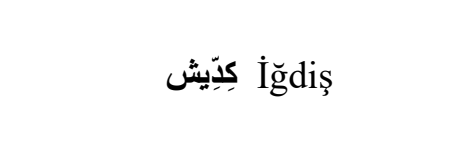 & $\begin{array}{l}\text { Eski Türk. igdiş "hizmetçi, besleme; ehlî hayvan" < igid } \\
\text { mek "eğitmek, yetiştirmek". [Kelimenin diğer anlamları } \\
\text { sonradan ortaya çımıştır]. }\end{array}$ \\
\hline 251 & كُرْبَاج Kırbaç & $\begin{array}{l}\text { Türk. < kır-maç) [Kelime Balkan dillerine, Arapça, Rusça, } \\
\text { Almanca ve Fransızca'ya da geçmiştir]. }\end{array}$ \\
\hline 252 & كُرَجَة / كُوَجَة & Türk. < göre+ce. \\
\hline 253 & كُرْك Kürk & $\begin{array}{l}\text { Eski Türkçe'den beri kullanılır; kökü belli değildir. [Kelime } \\
\text { Arapça, Farsça, Bulgarca ve Sırpça'ya da geçmiştir]. }\end{array}$ \\
\hline 254 & كَرَكَة & Türk. \\
\hline 255 & Karakol & $\begin{array}{l}\text { E. T. Türk. karavul "gözcü, nöbetçi; karakol” < Moğ. karaġul. } \\
\text { [Karakol şekline girmesinde Türkçe kol "asker" kelimesinin } \\
\text { etkisi olmalıdır; kelime Arapça, Kafkas ve Balkan dillerine de } \\
\text { geçmiştir]. }\end{array}$ \\
\hline 256 & Kürek كُرِيكَ / كُورِيك / كُورَك & Eski Türk. kürgek < kürigek < küri-mek "yeri eşmek". \\
\hline 257 & كَزْلَك Gezlik & Eski Türk. kezlik "çakı". \\
\hline 258 & كُزْلَك Gözlük & Eski Türk. $k o ̈ z<* k \ddot{o}-z+-$ lük. \\
\hline 259 & كَسِم Kesim & Türk. < kes-i-m. \\
\hline 260 & Kuşkonmaz & $\begin{array}{l}\text { Türk. kon-mak'tan isim-fiil ekinin kalıplaşmasıyle kuş kon- } \\
\text { maz. }\end{array}$ \\
\hline 261 & 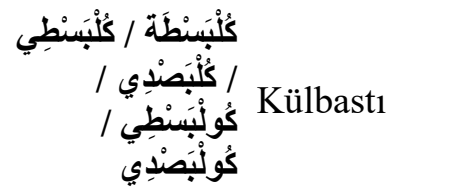 & $\begin{array}{l}\text { Türk. bas-mak'tan görülen geçmiş zaman ekinin } \\
\text { kalıplaşmasıyle kül bas-tt. }\end{array}$ \\
\hline 262 & كَلْبوش Kalpuş & Türk. \\
\hline
\end{tabular}


كُنَافَة Künefe

كَنْجِ İkinci كُنُْوز Kunduz

كُوبْرِي / كُوبْرِي Köprü

$$
\text { كُوزْك / كُرْكَ Kürk }
$$

$$
\text { كُوزَال Güzel }
$$

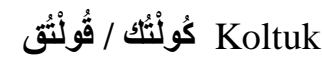<smiles>[134In]</smiles>

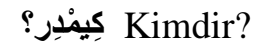

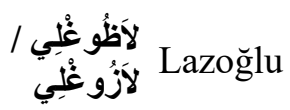

لتظانة Latzana
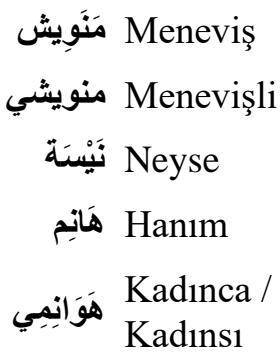

\section{Ocak}
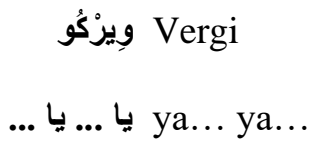

$$
\text { Yَاعَة / يَاقَّة }
$$

$$
\text { Yَيَإِزْجِي Yazırc1 }
$$

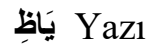

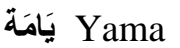

$$
\text { Yَيَامِيش Yemiş }
$$$$
\text { Yَيَاوَاش Yavaş }
$$

Türk. [Bazı kaynaklarda Arapça olduğu ifade edilmektedir.].

Eski Türk. ikki $+n c i$.

Eski Türkçe'den beri kullanılır; kökü belli değildir.

Eski Türk. köprüg; köpür-mek fiilinden türediği ileri sürülmüşse de kökü kesin olarak belli değildir. [Kelime Arapça'ya ve Balkan dillerine de geçmiştir].

Eski Türkçe'den beri kullanılır; kökü belli değildir. [Kelime Arapça, Farsça, Bulgarca ve Sırpça'ya da geçmiştir].

Türk. < gözel < göz+el.

Eski Türk. koltık-koltuk.

Türk.

Türk.

Türk.

Türk.

Türk. < menevş < Fars. benefş "menekşe rengi"nden.

Türk. < menevş < Fars. benefș "menekșe rengi"nden. + -li.

Türk. < ne+ise.

Türk. < hanım, han'dan iyelik ekinin kalıplaşmasıyle [?]

Türk.

Orta Türk. oçak< Eski Türk. ot "ateş". [Kelime Arapça, Farsça ve Rusça'ya, ayrıca Kafkas ve Balkan dillerine de geçmiştir].

Türk. $<$ ver-gi $<$ vir-gü $<$ Eski Türk. birgü $<$ birmek "vermek".

Türk.

Eski Türk. yaka "uç, sınır", yak-mak "yakın olmak”tan.

[Kelime Türkçe'den komşu dillere de geçmiştir].

Türk.

Eski Türk. yazı < yaz-mak "yaymak".

Eski Türk. yamag < yama-mak.

Eski Türk. yimiş; ye-mek kökünden geldiği ileri sürülmüşse de -miş ekinin buradaki fonksiyonu tam belli değildir; bâzı dilcilere göre ise yem $+i$ ş olarak açıklanabilir. [Kelime Türkçe'den Arapça ve Bulgarca'ya da geçmiştir].

Eski Türk. yavaş "yumuşak huylu, uysal". 


\begin{tabular}{|c|c|c|}
\hline 288 & يَاي Yay & $\begin{array}{l}\text { Eski Türk. yā; kelime daha sonra uzun } a \text { 'nın } \\
\text { etkisiyle yay biçimini almıştır. }\end{array}$ \\
\hline 289 & Yَيَِنْجِ Yedinci & Eski Türk. yitti - yiti $>$ yiddi $>$ yedi $+n c i$. \\
\hline 290 & يَشْنَكَك Yaşmak & $\begin{array}{l}\text { Eski Türk. yaş-mak "gizlenmek"ten fiil ismi ekinin } \\
\text { kalıplaşmasıle. [Kelime komşu dillere de geçmiştir]. }\end{array}$ \\
\hline 291 & بطُق Yatak & Türk. <yat-ak. \\
\hline 292 & يَفْفُور Yağmur & Türk. < yă̆-mur. \\
\hline 293 & يَفْمِيش Yanlış & Türk. yanıl-mak'tan fiil ismi ekinin kalıplaşmasıyle yanıl-ış. \\
\hline 294 & يَلْدِز Y1ldiz & $\begin{array}{l}\text { Eski Türk. yulduz, y'den dolayı düzleşme ile yılduz, ses uyumu } \\
\text { ile yıldız. }\end{array}$ \\
\hline 295 & يكَك Yelek & E. T. Türk. yelek "kuş kanadındaki tüy". \\
\hline 296 & يَلْكَنْجِي Yelkenci & Türk. < yel+ken $[?]+-$ ci. \\
\hline 297 & يَلْمَظ Y1maz & Türk. yll-mak'tan isim-fiil ekinin kalıplaşmasıyle yıl-maz. \\
\hline 298 & Yemekhane & Eski Türk. yi-mek ve Fars. hāne "ev, yer" ile yemek-ḩāne. \\
\hline 299 & Yَيَكَ Yemek & Eski Türk. yi-mek. \\
\hline 300 & يَمِيش Yemiş & $\begin{array}{l}\text { Eski Türk. yimiş; ye-mek kökünden geldiği ileri sürülmüşse } \\
\text { de -miş ekinin buradaki fonksiyonu tam belli değildir; bâzı } \\
\text { dilcilere göre ise yem +iş olarak açıklanabilir) [Kelime } \\
\text { Türkçe'den Arapça ve Bulgarca'ya da geçmiştir]. }\end{array}$ \\
\hline 301 & يَ يَوَش يَوَاش Yavaş Yavaş & Eski Türk. yavaş "yumuşak huylu, uysal”. \\
\hline 302 & يُوزَبَاثِبي Yüzbaş1 & Eski Türk. $y \bar{u} z+b \bar{a} s ̧+1$. \\
\hline 303 & يُوسُفَانْدِي Yusuf Efendi & Türk. \\
\hline 304 & 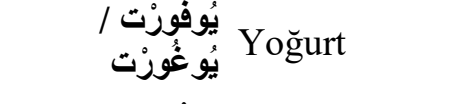 & Eski Türk. yuğurt < yuğur-mak "yoğurmak". \\
\hline 305 & يُوقْلَمَة Yoklama & Türk. yok+la-mak'tan. \\
\hline
\end{tabular}

\section{Türkçe + Arapça Kökenli Sözcükler}

Eski Türk. $i k k i+$ nci + Arap.

Eski Türk. bāss. + Ar. ri'āset "baş olmak"tan re'is.

Eski Türk. bāss. + Ar. ketb - kitābet "yazmak"tan kātib.

Eski Türk. $b \bar{a} s ̧ .+$ Ar. terceme'den mutercim.

Eski Türk. bāşs. + Ar. hadara'dan muhdır.

Eski Türk. bāş. + Ar. teftiş "araştırmak, denetlemek"ten mufettiş.

Eski Türk. $b \bar{a} s ̧ .+$ Ar. iftà " "fetvâ vermek" > mufti' den ses uyumu ile müftü. 
8

9

10

دُرْت نَعْل Dörtnal
Eski Türk. bāşs. + Ar. hendese'den muhendis.

Türk. < böl-ü-k. Emin: Ar. emn "korkusuz, güvenli olmak"tan emin. ( Osmanlı Devleti'nde bir ișin bașı ve sorumlusu durumunda olanlara verilen memûriyet unvânı).

Eski Türk. tört + Ar. na $\%$.

\section{Türkçe + Farsça Kökenli Sözcükler}

أيْتِن Ayten

Baştahta

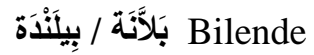

Bayraktar

Dörtçehar

دُوزْجِى Dört cihar
Türk. + Fars.

Eski Türk. bāşs. + Fars. tahte "biçilmiş ağaç".

Türk. bilmek’ten bil + Fars. ende.

Türk. bayrak ve Fars. dār "sâhip olan, tutan" ile bayrak-dār.

Eski Türk. tört + Fars. çehār $>$ çihār $>$ cihar.

Eski Türk. tört + Fars. çehār $>$ çihār $>$ cihar.

\section{Türkçe + Moğolca Kökenli Sözcükler}

$$
\text { Cيكَاش آغَا }
$$

\section{Yunanca Kökenli Sözcükler}

أزْغَاطَة Irgat

Arnavut

Istakoz

İstiridye

İskele

İskemle

Efendim

Efendi

Alay

Bodrum

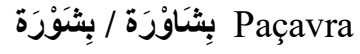

Pilaki

جَرْدَل
Yun. ergates.

Yun. Arvanitis < Arbanites; Arnavut şekli göçüşme ile ortaya çıkmıştır.

Yun. astakos - stakoz.

Yun. streidia.

Yun. skala $<$ Lat.

Yun. skamni $<$ Lat.

Yun. aféndis < authentês "kendi kendine iş gören; mutlak hâkim".

İyelik ekinin kalıplaşmasıyle $e f e n d i+m$

Yun. aféndis < authentês "kendi kendine iş gören; mutlak hâkim".

Yun. alayi < Bizans Yunancası allagion.

$<$ Yun. hypodromos.

Yun. patsavra [?].

Yun. plake.

Yun. kardari'den gerder, benzeşmezlikle gerdel. 


\begin{tabular}{|c|c|c|}
\hline 14 & جَلَفَط / قَلَفَاط Kalafat & Yun. kalaphates. \\
\hline 15 & / جُمْرُك جُمْرُج / Gümrük & < Yun. kumérkion < Lat. \\
\hline 16 & Gönder & $<$ Yun. kontari. \\
\hline 17 & كَاقيَّار Havyar & $\begin{array}{l}\text { Farsça hāaviyā } r \text { 'dan geldiği ileri sürülmüşse de son } \\
\text { incelemelere göre Yunanca bir türev kabul edilmektedir; } \\
\text { kelime Türkçe'den Arapça ve Avrupa dillerine de geçmiştir. }\end{array}$ \\
\hline 18 & Tirfil دِرْفِل & Yun. triphylli. \\
\hline 19 & Reçine & Yun. retsina. \\
\hline 20 & سَتْطَة & Yun. saltamarka. \\
\hline 21 & سِنَارَة & Yun. \\
\hline 22 & سنوسنتَة & Yun. sousta. \\
\hline 23 & صِرْمَة Sirma & Yun. syrma. \\
\hline 24 & طَبِْيَة Tabla & Yun. tabla $<$ Lat. tabula. \\
\hline 25 & Akrot & Yun. \\
\hline 26 & فَاصُولْيًَا Fasulye & Yun. phasoulia. \\
\hline 27 & فَانُوس Fanus & Yun. phanos. \\
\hline 28 & Gistan & $\begin{array}{l}\text { Yun. phoustani }<\text { İtal. fustagno. [Kelime Türkçe'den } \\
\text { Farsça'ya da geçmiştir]. }\end{array}$ \\
\hline 29 & فَنَار Fener & Yun. phanari. \\
\hline 30 & قَََْْان Kaytan & $\begin{array}{l}\text { Yun. gaitani < Lat.. [Kelime Arapça, Farsça, Bulgarca ve } \\
\text { Sirpça'ya da geçmiştir]. }\end{array}$ \\
\hline 31 & كُرَويَّة & Yun. krebati. \\
\hline 32 & كرِيز Kiraz & Yun. kerasi. \\
\hline 33 & كُوَبَتْنَّة Küpeşte & Yun. koupaste. \\
\hline 34 & Lلأكَرْدَة Lakerda & Yun. lakérda < Lat. \\
\hline 35 & Lلاَمْبَة Lamba & Yun. lampá. \\
\hline 36 & لِيمَان Liman & Yun. liménion > limáni. \\
\hline 37 & Masura & Yun. masuri. \\
\hline 38 & مَنْجَلَة & Yun. mangano. \\
\hline 39 & مَنْدِيل Mendil & Yun. manteli. [Kelime Arapça ve Farsça'ya da geçmiştir]. \\
\hline
\end{tabular}

35. Yunanca + Farsça Kökenli Sözcükler

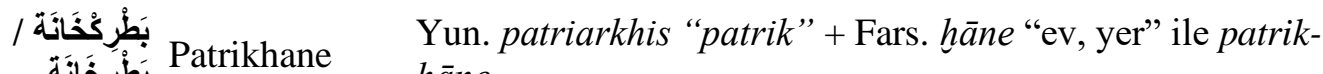 hāne.
مُطْرَانْخَانَة Mutranhane $\quad$ Yun. mutrân + Fars. hāne “ev, yer”.


36. Yunanca + Türkçe Kökenli Sözcükler

1

2

3

4

5

Yun. temelion + Türk. -li.

Yun. kumérkion < Lat. + Türk. -ci.

Yun. kontaki + Türk. -ç1.

Yun. lakhóma + Türk. -c1.

Yun. verniki < berenike. [Kuzey Afrika'da Bingazi yakınındaki Berenike şehrinin adından] + Türk. -çi.

\section{Kökeni Belli Olmayan Sözcükler}

1

2

3

4

5

6

7

8

9

10

11

12

13

14

15
أُرْمَان / أُوْْمَان Orman

Örnek

Ökçe

بَابًَا Baba

Pَبَثَا Paşa

بُغْدَادْلِي $B a g ̆ d a t l 1$

Peksimet

Börek

Pul بُول Pul

Tَزَس

Teneke

Teتَكَثِي Tenekeci

جَابَا Caba

Hayırsız

دادي Dâdî
Kökü kesin olarak belli değildir; Eski Türk. or "hendek, çukur"dan +man ekiyle türetilmiş olabileceği ileri sürülmüştür.

Kökü hakkında çeşitli görüşler ileri sürülmüş, bu arada körmek > gör-mek fiilinden veya ör-mek'ten [< ör-enek] türediği söylenmiştir; öte yandan kelimenin Ermenice orinak aracılığ 1 ile Orta Farsça'dan Türkçe'ye geçtiği iddia edilmiştir; ancak diğer Türk lehçelerinde de benzer şekillerde bulunduğundan Türkçe asıllı olduğu görüşü daha güçlü sayılmalıdır.

Kökü belli değildir. [Türkiye Türkçesi'nde XIV. yüzyıldan beri görülmektedir]

Kökü belli değildir. [Başka dillerde de benzer biçimde kullanılmaktadır]

Kökü kesin olarak belli değildir; Türk. beşe "ağabey"den, baş $a \breve{g} a$ ' dan veya Fars. $p a \hat{y}$ - $i$ şâh "şâhın ayağı, şâhın sağ kolu" tamlamasından gelmiş olabileceği ileri sürülmüsstür.

[Kelime $b \bar{a} s ̧ \bar{a}$ söyleyişiyle Arapça'ya, pāşā şeklinde Farsça'ya geçmiş, ayrıca Balkan ve Kafkas dillerine de girmiştir].

Bağdat [Kökeni tartışmalıdır] + Türk. -li.

Yun. paksimadi veya Fars. beksimāt'tan. [Kelimenin asıl kökü ve hangi dilden Türkçe'ye geçtiği kesin olarak belli değildir].

Kökü kesin olarak belli değildir. Kelime Türkçe'den Farsça Rusça ve diğer dillere de geçmiştir.

Türkçe olmayan bu kelimenin etimolojisiyle ilgili kesin bir sonuca varılamamıştır.

Kökü belli değildir.

Kökü belli değildir.

Teneke: Kökü belli değildir. + Türk. -ci

Kökü belli değildir.

Kökü kesin olarak belli değildir; hayırsız'ın yıpranmış şekli olabilir.

Kökeni belli değildir, ses taklidi olabilir. 


\begin{tabular}{|c|c|c|}
\hline 16 & دُنجُْل Dingil & Kökü belli değildir. \\
\hline 17 & 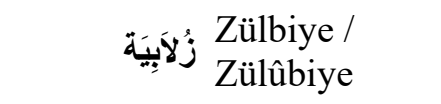 & $\begin{array}{l}\text { Kökü tartışmalıdır. Bazı kaynaklar Arapça olduğunu } \\
\text { söylemektedir. }\end{array}$ \\
\hline 18 & 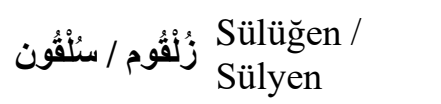 & Kökü belli değildir. \\
\hline 19 & زَهْر Zar & Kökü belli değildir. \\
\hline 20 & Sucuk سُجُق & Kökü belli değildir. \\
\hline 21 & سِرِاجَة Siraca & Kökü bulunamamıştır. \\
\hline 22 & S Şarmuta & $\begin{array}{l}\text { Kelimenin kökeni tartışmalıdır. Fransızca, Kıptîce ve İbranice } \\
\text { olduğu da söylenmiştir. }\end{array}$ \\
\hline 23 & شَتَتَنَة / شَّلَيَّة & $\begin{array}{l}\text { Yunanca olabileceği ileri sürülmüşse de kökü kesin olarak } \\
\text { belli değildir. }\end{array}$ \\
\hline 24 & 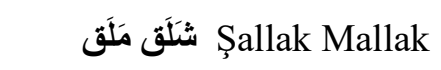 & Kökü bulunamamıştır; ses taklidi kelime olabilir. \\
\hline 25 & شُنْنَيَان Çintiyan & Kökü belli değildir. \\
\hline 26 & صَنْدَل Sandal & Kökü bulunamamıştır. \\
\hline 27 & Tabur & $\begin{array}{l}\text { Kökü kesin olarak belli değildir; bâzı dilciler bu kelime ile } \\
\text { Mac. tabór arasında bir ilişki kurar. }\end{array}$ \\
\hline 28 & طَنْجَرَة Tencere & Kökü bulunamamıştır. \\
\hline 29 & طَوَان Tavan & Kökü belli değildir. \\
\hline 30 & طُوَة Tura & Kökü bulunamamıştır. \\
\hline 31 & فُشَكَتِلِك Fişeklik & Kökü kesin olarak belli değildir. fişek + Türk. -lik. \\
\hline 32 & 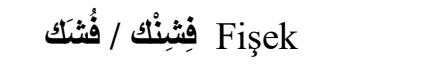 & Kökü kesin olarak belli değildir. \\
\hline 33 & قََارْجِغَار Karciğar & Kökü bulunamamıştır. \\
\hline 34 & 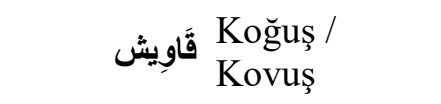 & Kökü bulunamamıştır. \\
\hline 35 & كَديسنَة Kedi & Kökü belli değildir. \\
\hline 36 & Lلَبَة / لَبَخَة & Kökü belli değildir. \\
\hline 37 & مَتْتَم Meltem & Kökü belli değildir. \\
\hline 38 & مُور Mor & $\begin{array}{l}\text { Kökü hakkında bâzı görüşler ileri sürülmüşse de kesin bir } \\
\text { sonuca ulaşılamamışır. }\end{array}$ \\
\hline
\end{tabular}

\section{Sonuç}

Tespit edebildiğimiz kadarıyla Türkçe aracılığıyla Mısır Arapçasına geçen sözcükler 36 farklı kökende ve türdedir. Ayrıca 38 adet kökeni belirlenemeyen sözcük vardır.

Mısır lehçesine Türkçe aracılığıyla geçtiğini belirleyebildiğimiz 995 sözcüğün yaklaşık üçte biri (305 tanesi) Türkçe'dir. Bu türden kelimelerin önemli bir bölümünün, yaklaşık üçte ikisinin (189) Eski Türkçe'den beri kullanılan kelimeler olduğu gözlemlenmiştir. "Eski, oyun, parmak, burma, beş, bakraç, balta, çavuş, çok, kargaşa, dağ, demir, sancak, süngü, çekiç, çevirme, şiş, şiş 
tavuk, sarma, sol, topuk, tuz, aşçı, kazan, kazık, kışlak, kol, kürk, yaka, yemiş, yaşmak, yıldız, yavaş, yoğurt” gibi kelimeler bu türden kelimeler arasındadır.

Eski Türkçe kelimelerin yanı sıra "pekmez, tatlı, çörek, çıkma, sağ, tuğra, kapı, koç, ocak, bardak" gibi Orta Türkçe kelimeler de bulunmaktadır.

“Ökçe, çilek, kıç” gibi birtakım sözcüklerin ise Türkiye Türkçesi’nden geçtikleri gözlemlenmiştir.

Ayrıca "ikinci kalem, başreis, başkatip, başmütercim, başmuhdır, başmüfettiş, başmüftü, başmühendis, bölük emini, dörtnal" kelimelerinin Türkçe + Arapça kökenli; "ayten, baştahta, bilende, bayraktar, dörtçehar, dört cihar" kelimelerinin Türkçe + Farsça kökenli; "başağa" kelimesinin ise Türkçe + Moğolca kökenli olduğu görülmüştür.

$\mathrm{Bu}$ türden kelimelerin yanı sıra "ahlaksız, işaretçi, tahsilci, terbiyesiz, haremlik, haşmetli, hekimbaşı, dükkancı, silahlık, şerbetli, fitneci, kumarcı, mabeyinci, hazırdur / hazrol" gibi Arapça + Türkçe; "astarc1, bostanc1, tüfekçi, hanc1, hastalanmak, sofrac1, sabuncu, ateşçi, kilerci, kemençe, nazlı, nevin, yağmacı" gibi Farsça + Türkçe; "avantacı, valfçı, tpompetçi, taksici, telgrafçı, televizyoncu, gazeteci, komisyoncu" gibi Fransızca + Türkçe; "postac1, tiyatrocu, dümenci, tavlacı, tulumbacı, kunduracı, lokantacı, makinacı" gibi İtalyanca + Türkçe; "temelli, gümrükçü, kundakçı, lağımcı, vernikçi” gibi Yunanca + Türkçe; "telli, şenlik” gibi Ermenice + Türkçe kelimeler de Mısır Arapçasında yer almaktadır.

"Eczaneci" kelimesi ise Arapça + Farsça + Türkçe bir kelime olarak; "Asvanlı" kelimesi ise Eski Mısır + Türkçe kökenli bir sözcük olarak göze çarpmaktadır.

Mısır lehçesindeki Türkçe kökenli sözcükleri, Farsça'dan Türkçe’ye, oradan da Mısır Arapçasına geçen sözcükler takip etmektedir. "Âşikâr, usta, işkembe, enişte, pabuç, para, perde, puşt, piyade, peçe, tava, tımar, çavdar, çift, zincir, hatun, hastahane, hoşaf, tane, dilber, zindan, sepet, sert, sincap, şadırvan, çeşni, çamaşır, torba, turşu, aferin, anbar, kahraman, köşk, kilim, menteşe, nine, yahni, yağma" gibi örnekler verebileceğimiz bu türden 238 sözcük tespit edilmiştir.

Mısır Arapçasında tespit edebildiğimiz kadarıyla 57 Arapça kökenli sözcük de bulunmaktadır. Bu türden, özellikle isim olarak kullanılan bazı kelimelerle ilgili olarak, şöyle bir durum söz konusudur.

Arapçada (ö) ile biten kelimeler, Osmanlı Türkçesinin etkisiyle ت'li adlara dönüşmektedir. Misır Arapçasında bu türden isimlere sıkça rastlanmaktadır. Örneğin Arapça (نصرة) kelimesi, Osmanlıcada (نصرت) şeklinde yazılmaktadır. Mısır Arapçasına da bu şekilde geçtiği görülmektedir. $\mathrm{Bu}$ türden bazı adları şu şekilde sıralamak mümkündür. Behçet, Cevdet, Fikret, Hâlet, Heybet, Hidâyet, Hikmet, Himmet, İffet, İnâyet, İsmet, İzzet, Kudret, Mithat, Necdet, Nimet, Nusret, Nüzhet, Saffet, Servet, Şevket, Talat, Ülfet, Ziynet.

Ayrıca Osmanlı Türkçesinde (ي-1) ile biten adlara (î) eki getirilerek Osmanlı Türkçesinde özel adlar oluşturulmuştur. Arapçada olmayan bu türden adlar Osmanlı Türkçenin etkisiyle Arapçada da görülmektedir. Bu türden adlardan bazıları şunlardır Abdî, Adlî, Avnî, Azmî, Bedrî, Fehmî, Fahrî, Fethî, Fevzî, Feyzî, Fikrî, Şevkî, Şükrî, Hakkî, Hamdî, Hayrî, Hilmî, Kadrî, Lutfî, Mecdî, Nazmî, Nûrî, Remzî, Rüşdî, Rûhî, Sadî, Sabrî, Seyfî, Sirrî, Subhî, Turkî, Ulvî, Vecdî, Vehbî, Vasfî, Zihnî, Zuhdî.

Mısır lehçesine Türkçe'den geçen Arapça kökenli sözcüklerin bazılarının Türkçe'de yeni anlam kazanan ve bu anlamlarıyla Mısır Arapçasına geçen sözcükler oldukları müşahede edilmiştir. Örneğin (أمَان / Aman) kelimesi, Araça أمان kelimesinden gelmekte ve "emin olma, emin k1lma, emniyet" gibi anlamları dile getirmektedir. Ancak kelime Arapçadaki anlamlarından farklı olarak, dilimizde çeşitli duyguları ifâde eden cümlelerde anlamı güçlendirmek için kullanılmaktadır ve Mısır Arapçasına da bu şekliyle geçmiştir.

Turkish Studies - Social, 15(3) 
Misır lehçesine Türkçe'den geçtiğini belirleyebildiğimiz kelimelerden bazıları ise Arapça + Farsça kökenli sözcüklerdir. Bu türden kelimelerin sayısı 26'dır. "Eczane, belki, cüzdan, hapishane, hükümdar, hazinedar, rasathane, silahtar, şifahane, kütüphane, misafirhane, makasdar, mühendishane, nizamnane" gibi kelimeler bu türün örneklerini oluşturmaktadır.

Mısır Arapçasındaki Türkçe ve Farsça kökenli sözcükleri, sırasıyla İtalyanca, Fransızca ve Yunanca sözcüklerin takip ettiği gözlemlenmiştir.

Aşağıdaki tablo Mısır Arapçasındaki sözcüklerin kökenleriyle ilgili genel görünümü net bir şekilde ortaya koymaktadır.

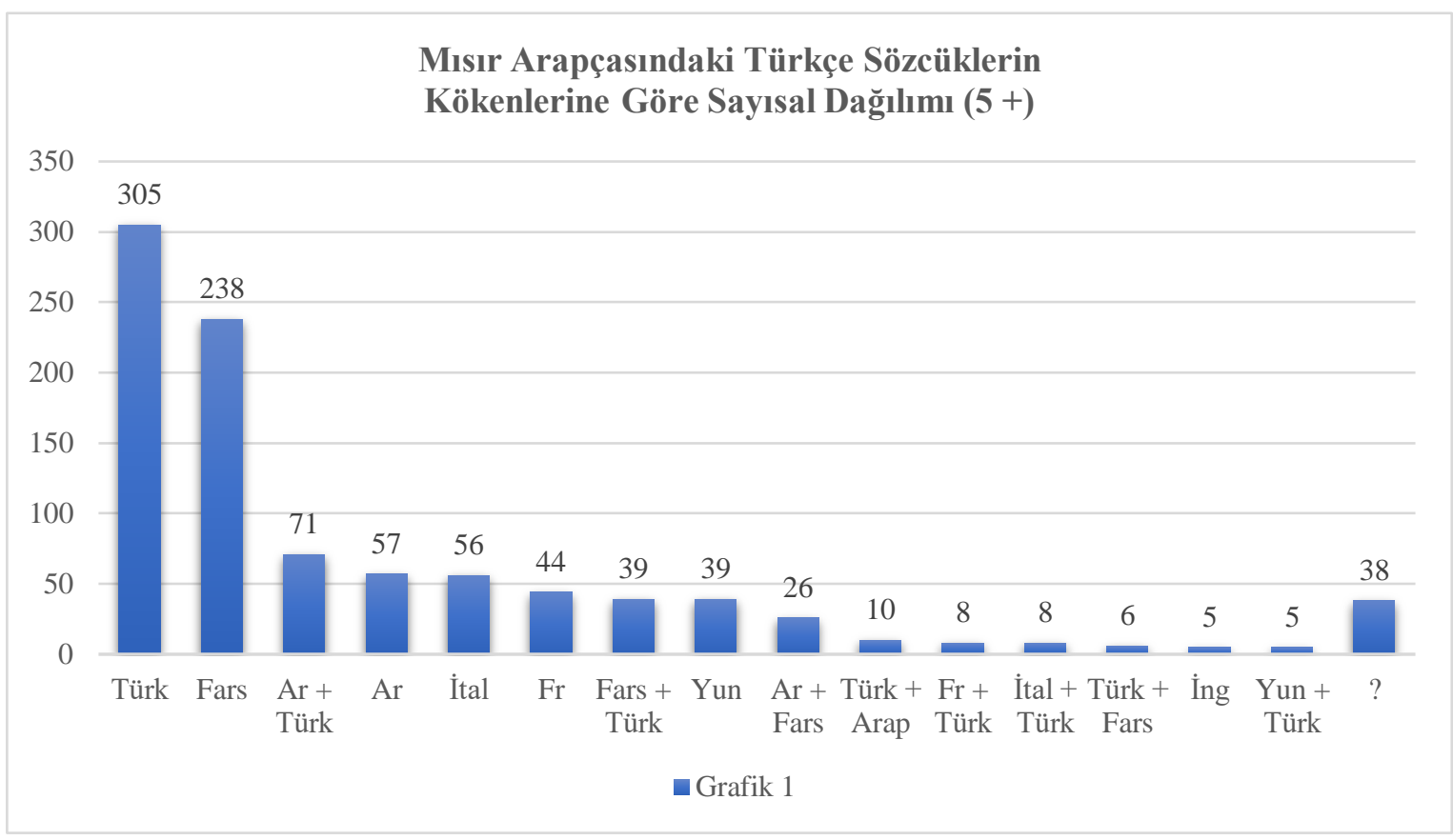
şöyledir:

Bu tabloda en az beş ve üzerindeki sözcüklere yer verilmiştir. Beş’ten aşağısında durum

Farsça + Arapça kökenli 4; Almanca, Bulgarca, Ermenice, Ermenice + Türkçe, Macarca, Moğolca, Moğolca + Farsça ve Yunanca + Farsça kökenli 2'şer; Arapça + Farsça + Türkçe, Çince, Eski Mısır + Türkçe, Farsça + Yunanca ve Fransızca + Farsça 1'er sözcük yer almaktadır.

\section{Kaynakça}

Abdu'd-Dâyim, Muhammed. (2004). el-Kelimâtü't-Türkiyye fi'l-Luğati'l-Arabiyye ve'l-Lehceti'sSûriyye.

Abuşvereb, Abdulkerîm. (1986). el-Kelimāt ül-'Osmaniyye fi'l Lehcetil'- Libiyye, Studies on Turkish-Arab Relations Annual. 1, İstanbul, 6-12.

Akar, Ali. (2010). Türkçe-Arapça Arasındaki Sözcük İlişkileri. Karadeniz Sosyal Bilimler Dergisi, say1: 8, 9-16.

Allûb, Abdülvehhâb. (2014). ed-Dahîl fi'l-Âmmiyyeti'l-Mısriyye. Kahire: el-Merkezu'l-Kavmî li’tTercüme. 
Ateş, Ahmet. (1966). Arapça Yazı Dilinde Türkçe Kelimeler, 10. Yüzyıla Kadar. Türk Kültürü Araştırmaları II, Ankara, 5-25.

Avcı, Necati. (1996). Libya Yerel Arapçasında Kullanılan Türkçe Kelimeler, Erciyes Üniversitesi Ilahiyat Fakültesi Dergisi, 9, 147-157.

Avn, Şerif Kasım. (2002). Kamusu'l-Lehce'tü'l- 'Ammiyye Fi's-Sudan, Hartum: Daru's-Sudaniyye li'l-Kutub.

Aytaç, Bedrettin. (1994). Arap Lehçelerindeki Türkçe Kelimeler. İstanbul: Türk Dünyas1 Araştırmaları Vakfi.

Ayverdi, Z.İ. Kubbealtı Lügatı. http://lugatim.com

Bayatlı, Hidayet Kemal. (1993). Irak Arapçasında Türkçe Sözcük ve Terimler, Dil Dergisi 14, 6066.

Bechraoui, Mohammed-Fadhel. (2002, Bahar). Türk Dilinin Tunus'taki Tarihi: Örnekler ve Evreler, Milli Folklor Dergisi, 53, 126-160.

Belguedj, Mohammed Salah. (1971). Le mots turcs dan le parler algèrien, Turcica, 3, 133-142.

Çetin, M. Nihad. (1991). Ateş, Ahmet, Diyanet vakfi islam ansiklopedisi, Erişim Tarihi: 30.09.2018. https://islamansiklopedisi.org.tr/ates-ahmet

Duhman, Mahammad Ahmad. (1990). Mucemu'l-Elfazu't- Tarihiyye fi-Asri'l-Mamalukiya (Dictionary of Historical Mamluk's Words and Expressions), Şam:

el-Ekü, İsmail bin 'Ali. (1985). Kelimat Türkiyye Mus-ta'mele fi'l Yemen, el-Eklîl, 49-58.

El-Mısratî, Ali Mustafa. (1968). Libya-Türkiye Arasındaki Tarihi Ilişskiler. Trablus:

el-Misrî, Hüseyn Mucib. (1967). et-Türkiyye fi'l-Ammiyyeti'l-Misriyye, el-Mecelletü'tTarihiyyeti'l-Misriyye, XXIII, Kahire. 385-393.

Emad, Atilla. (2013). Ürdün Lehçesinde Türkçe Kökenli Kelimeler. Erzurum: Atatürk Üniversitesi, Sosyal Bilimler Enstitüsü, Doğu Dilleri ve Edebiyatları Anabilim Dalı.

Eren, Hasan. (1997). Halas1-Kun, Tibor, Diyanet vakfi islam ansiklopedisi, Erişim Tarihi: 30.09.2018. https://islamansiklopedisi.org.tr/halasi-kun-tibor

Fazlığlu, Şükran. (2016). Mahfuz, Hüseyin Ali, Diyanet vakfi islam ansiklopedisi, Erişim Tarihi: 30.09.2018. https://islamansiklopedisi.org.tr/mahfuz-huseyin-ali

Gamal, Fady Adly Gouny. (2017). Mısır Arapçasındaki Türkçe Unsurlar, Uluturkad, c:2, sayı: 1, 120.

Gedik, Sadi. ve Al Berro, Shaze. (2016). Türkçe-Arapça Dil İlişkileri Bağlamında Muhammed Hayruddin El-Esedi'nin Halep Ansiklopedisi Üzerine Bir Değerlendirme, International Journal of Languages' Education and Teaching, y1l:4, say1: 2, 314-328.

Ghazi, Abdallah. (1990). Türkçe'nin Ürdün ve Suriye Lehçeleri'ne Etkisi, Yüksek Lisans Tezi, Ankara: Ankara Üniversitesi.

Guella, Noureddine (2011). Emprunts Lexicaux dans des Dialectes Arabes Algèriens, Synergies Monde arabe, 8, 81-88.

Guella, Noureddine. (2011). Emprunts Lexicaux dans des Dialectes Arabes Algèriens, Synergies Monde Arabe, 8, 81-88. 
Gülensoy, Tuncer. (1975). Yaşayan Farsça ve Arapçadaki Türkçe Kelimeler Üzerine Notlar, İstanbul Üniversitesi Edebiyat Fakültesi Türk Dili ve Edebiyatı Dergisi, 21, 127-157.

Gülensoy, Tuncer. (2007). Türkiye Türkçesindeki Türkçe Sözcüklerin Köken Bilgisi Sözlüğü. Ankara: Türk Dil Kurumu.

Güney, Fatma Şahan. (2018). Cezayir Arapçasına Osmanlıcadan Geçen Türkçe Kelimeler Ve Osmanlı Dönemi Cezayir'inde Günlük Hayat. Erişim tarihi: 24.08.2018, https://www.researchgate.net

Hazım, Naim. (1933). Arap Dilinde Türkçe, Ankara: Hâkimiyeti Milliye Matbaası.

İnan, Abdülkadir, (1953). XIII ve XVI. Yüzyıllarda Mısır'da Oğuz-Türkmen ve Kıpçak Lehçeleri ve Halis Türkçe, Belleten, 53-71.

İsa, Ahmed. (1939). El-Muhkem Fî Usûli'l-Kelimâti'l-Âmmiyye. Kahire: Matbaatu Mustafa el-Bâbî el-Halebî.

Kanar, Mehmet. (2003). Litmann, Enno, Diyanet vakfi islam ansiklopedisi, Erişim tarihi: 30.09.2018. https://islamansiklopedisi.org.tr/littmann-enno

Karaağaç, Günay. (2008), Türkçe Verintiler Sözlüğü. Ankara: Türk Dil Kurumu Yayınları.

Karaağaç, Günay. Türkçenin Dünya Dillerine Etkisi, Erişim tarihi: 24 Ağustos 2018. http://turkoloji.cu.edu.tr

Kaymaz, Zeki (1983). Sudan Arapçasındaki Türkçe Söz Varlığı Üzerine, İzmir: Türk Dünyas1 Araştırmaları Enstitüsü-Bornova.

Littmann, Enno. (1954). Türkisches Sprachgut im Agyptisch-Arabischen. Westostliche Abhandlungen Wiesbaden, 107-127.

Magdi, Bakr Abdel Monsef. (2009). Arapçada Türkçe Sözvarlığının Etkileri, Şarkiyat Mecmuası 14, 27-37.

Mahfüz, Hüseyn Alî. (1964). el-Elfâzu't-Turkiyye fi'l-Lehceti'l-'Irâkiyye, et-Turâsu'ş-Şa'bî, VI, Bağdat, 1-24 (ayrı basım).

Muhammad bin Chanab. (1966). Cezayir Konuşma Dilinde Muhafaza Edilen Türkçe ve (Türkçe aracılığı ile gelen) Farsça Kelimeler (Ateş, Ahmed Çev.) Ankara: Türk Dili Araştırmaları Y1llı̆̆ 1 Belleten, 157-213.

Mütevelli, Ahmed Fuad (1991). el-Elfazü't-Türkiyye Fi 'l-Lehecâti'l 'Arabiyye ve Fi Lugat'il-Kitâbe, Kahire: Dar üz-Zehrâ Li'n-Neşr.

Mütevelli, Ahmet Fuat, (1985). Arap Halk Dilinde Türkçe Kelimeler, Türk Halk Edebiyatında ve Folklorunda Yeni Görüsler II, Konya: Konya Kültür ve Turizm Derneği Yayınları.

Oğuz, M. Öcal. (2000). Belguedj'in Makalesine Göre Cezayir Konuşma Dilindeki Türkçe Kelimeler ve Tunus'taki Durum, Milli Folklor, 46, 10-21.

Öz, Mustafa. (1999). İbn Ebû Şeneb, Diyanet vakfi islam ansiklopedisi, Erişim Tarihi: 30.09.2018. https://islamansiklopedisi.org.tr/ibn-ebu-seneb

Özdemir, H. (1990). Tunus ve Civarında Yaşayan Türkçemiz, Türk Dünyası Araştırmaları, 64, 153 168.

Özkan, Öztekten. (2004). Türkçenin Dünya Dillerine Etkisine Genel Bir Bakış, V. Lefke Edebiyat Buluşmast-Türkçenin Dünya Dillerine Etkisi, Ankara, 5-20. 
Prokosch, Erich. (1983). Osmanisches Wortgut im Agyptisch-Arabischen, Berlin: Klaus Schwarz Verlag.

Prokosch, Erich. (1983). Osmanisches Wortgut im Sudan-Arabischen, Berlin: Klaus Schwarz verlag.

Saussey, R. E. (1929). Les Mots Tures Dans Le Dialecte De Damas, Dımeşk: 75-129.

Şahhâte, Hasîb. (2010). Kelimat Türkiyyetu'l-Asl Dahîle fi'l-Arabiyye, Erişim tarihi: 25 Ağustos 2018. https://pulpit.alwatanvoice.com/articles/2010/10/19/212174.html

Şahin, Abdussabur. (1994). İsti'mâlât Türkiyye fi'l-Âmmiyyeti'l-Mısriyye. Erişim tarihi: 11 Eylül 2018, http://wamadat.forumegypt.net/t8643-topic.

TDK. Türkçe Sözlük. https://sozluk.gov.tr

Tibor, Halasi-Kun. (1969). The Ottoman Elements in The Syrian Dialects, Archivum Ottomanicum 1, Miuton, 14-91; 5 (1973). 17-95; 7 (1982). 117-267.

Turapbaykızı, Aljanbaeva Ulbala. (1999). Arab Tilindegi Türkizmder. Doktora Tezi, Almaty: ElFarabi Kazak Devlet Üniversitesi.

Türkmani, Khadija. (2015), Suriye Arapçasındaki Türkçe Unsurlar. (Yüksek Lisans Tezi) Kayseri: Erciyes Üniversitesi Sosyal Bilimler Enstitüsü.

Türkmen Erkan, (2015). Arapçanın Libya Lehçesindeki Türkçe Kelimeler, Erdem, 10 (10), 211-225.

Türkmen, Erkan. (1988). Turkish Words in the Libyan Dialect of Arabic, Erdem, Atatürk Kültür Merkezi Dergisi IV, Ankara: Türk Tarih Kurumu Basımevi, 227-243.

Uysal, Halil (2018). Mısır Lehçesindeki Türkçe Kelimeler I, Journal of Current Researches on Social Sciences, 8 (4), 113-162.

Uysal, Halil (2018). Misır Lehçesindeki Türkçe Kelimeler II, Journal of Current Researches on Social Sciences, 8 (4), 163-214.

Uzun, Mustafa. (2016). Mısrî, Hüseyin Mücîb, Diyanet vakfi islam ansiklopedisi, Erişim Tarihi: 30.09.2018. https://islamansiklopedisi.org.tr/misri-huseyin-mucib

Yahya, Şamil Fahri. (1984). Arapçanın Muhtelif Lehçelerinde Türkçe Unsurlar, (doktora tezi). İstanbul: İstanbul Üniversitesi.

Yahya, Younis Ahmed Adam. (2017). Sudan Arapçası'ndaki Türkçe Kökenli Kelimeler: Fonetik ve Semantik Değişimler. Erişim tarihi: 24 Ağustos 2018. afam.org.tr

Zülfikar, Tüccar. (2007). Onat, Naim Hazım, Diyanet vakfi islam ansiklopedisi, Erişim Tarihi: 30.09.2018. https://islamansiklopedisi.org.tr/onat-naim-hazim 